\title{
TEMPO E MELANCOLIA: REPÚBLICA, MODERNIDADE E CIDADANIA NEGRA NOS CONTOS DE ASTOLFO MARQUES (1876-1918)
}

\author{
Matheus Gato de Jesus
}

Um artista habilíssimo atacara certos atos, aliás muito censuráveis, da Junta.

Paula mandou chamá-lo e inquiriu-o em voz estentória como se atrevera a tanto. - Eu pensei... - começava a defender-se o interrogado. - Já viste negro pensar? És besta, negro, roubaste de autores, e vais para a cadeia!...

$E$, depois do homem sair preso, voltando-se para o chefe de polícia, que era Casimiro Júnior:

- Casimiro, quando ele te definir o que é pensamento, solta-o... (Domingos Barbosa, [1911] 2008, p. 44-45).

O homem tem mesmo raiva de negro! Onde ele vê um negro, vê desde logo um inimigo a combater!! Fecham-se-lhe o espírito e alma! Ele já disse uma vez que negro é moleque, e ele suporta um negro por... excesso de civilização! E então, para esmagar os negros, ele conta um fato que se deu com o Prazeres de Freitas, no Teatro São Luis:

- E já viste um negro pensar? Perguntou o Paula Duarte. - Lobo quando chega a este ponto, levanta-se, dá duas voltas, a rir, satisfeito, porque para ele a frase de Paula Duarte é esmagadora! E repete:

- E já viste um negro pensar?

Mas que professor e que jornalista republicano é Lobo! (Nascimento Moraes, 1910, P. 9). 
O fato narrado nas duas versões acima parece ter se tornado, na virada do século XIX, uma piada bastante conhecida acerca da Proclamação da República em São Luís do Maranhão. O desagravo do escritor e jornalista negro José do Nascimento Moraes (1882-1958) sugere que a conversa era utilizada para humilhar e ridicularizar pessoas negras no período pós-Abolição ${ }^{1}$. Tratava-se de uma das muitas polêmicas envolvendo o nome de Francisco de Paula Belfort Duarte, mais conhecido simplesmente como Paula Duarte, membro da Junta Provisória que assumiu o controle da província em adesão ao regime instituído no país no dia 15 de novembro de $1889^{2}$. Para seu admirador Domingos Barbosa (1880-1945) o republicano histórico "foi um desses tipos que ficam na memória dos homens, envolvidos numa bruma, e que após si deixam inevitavelmente uma trama de lendas, que os anos e as gerações inevitavelmente tecem ([1911] 2008, p. 41).

134 É nesse espírito de esticar um pouco mais o tecido da memória, para manter a bela metáfora do autor, que o acontecimento é narrado. Misto de fato histórico verídico e "trama de lendas, que os anos e as gerações inevitavelmente tecem”, a anedota fazia rir ao confrontar a prisão injusta

1 O escritor maranhense José do Nascimento Moraes (1882-1958) foi professor, jornalista, poeta, crítico literário e romancista. Seus principais trabalhos publicados são o conjunto de ensaios de crítica literária e social intitulada Puxos e repuxos (1910), o romance Vencidos e degenerados (1915), e o ensaio político Neurose do medo (1923). Deixou inédito o livro de poesias Círculos, sem que seja possível precisar a data de composição, além de uma gama de contos não publicados. Foi fundador da revista literária Athenas e, como jornalista, trabalhou para diversos jornais maranhenses como, dentre outros, A Campanha, O Maranhão, A Pátria, Diário de São Luis, O Jornal, A Tribuna, A Hora, Diário do Norte, Diário Oficial, O Globo, Correio da Tarde, A Imprensa, Notícias.

2 Francisco de Paula Belfort Duarte nasceu em 1841 e morreu na primeira década do século XX, em data desconhecida. Bacharelou-se na Faculdade Direito de São Paulo em 1864 e, regressando à sua província, exerceu as funções de jornalista, advogado, deputado geral pelo Maranhão (1867-1868), deputado provincial (18801881). Foi o único membro civil e "republicano histórico" que compôs o primeiro governo provisório republicano no Maranhão (18/11/1889-17/12/1889). Para maiores detalhes ver Coutinho (2007). 
de um homem do povo e sua esdrúxula justificava racial. A autoridade pública parece se irritar ao ouvir o verbo "pensei" da boca de um negro que criticara o governo e lhe dirige uma acusação ilógica ("roubaste de autores"), levando-o para cadeia como uma espécie de desafio intelectual: caso conseguisse definir o que é pensamento seria solto.

Essa pequena estória constitui um precioso registro dos significados sociais do advento da República brasileira ${ }^{3}$. Ela nos permite cotejar a história na trama da memória coletiva: o modo como um acontecimento político pode encarnar-se duradouramente nas maneiras com que um povo aprende a rir da sua própria violência. No caso dessa anedota, o senso do humor, seja para os que se divertiram ou aqueles que se irritaram, emerge da relação entre a total arbitrariedade de um poder que deveria ser legítimo e a factibilidade irracional de seu exercício. A raça é literalmente ridícula: o autoritarismo da nova ordem é levado ao paroxismo.

$\mathrm{O}$ incidente narrado expunha em primeira hora o modo pelo qual as aspirações por liberdade, igualdade e fraternidade despertadas pela Abolição da Escravidão e o fim da Monarquia foram imediatamente frustradas pela clivagem social e racial da cidadania no país. Fato tanto mais significativo quando sabemos por parcos registros historiográficos que Prazeres de Freitas, a provável vítima da humilhação seguida de encarceramento, era um proeminente abolicionista maranhense. Note-se a ironia da frase lapidar de Nascimento Moraes ao revidar a injúria: "Mas que professor e que jornalista republicano é Lobo"4.

\footnotetext{
3 Remeto o leitor para anotação metodológica de Robert Darnton que inspira esta reflexão: "Quando se percebe que não se está entendendo alguma coisa uma piada, um provérbio, uma cerimônia - particularmente significativa para os nativos, existe a possibilidade de se descobrir onde captar um sistema estranho de significação, a fim de decifrá-lo" (1986, p. 106).

4 Antonio Leal Lobo (1870-1916) iniciou seus estudos no Colégio de São Paulo e adentrou no Liceu Maranhense. Depois de formado, assumiu a cadeira de docente na instrução pública. Como possuía inserção e parentesco com figuras
} 
$\mathrm{O}$ acontecimento também revela o contexto mais tenso da adesão ao governo do general Deodoro da Fonseca nas províncias mais longínquas do Império. O movimento republicano no Maranhão é muito tardio e apenas ganhou vulto entre os setores mais expressivos da elite após a lei de 13 de Maio de 1888. As promessas jamais cumpridas de indenização aos senhores pela expropriação da mão de obra escravizada e os projetos malogrados de imigração estrangeira foram um Leimotiv político bastante sedutor à causa da liberdade dos brancos ${ }^{5}$. Não espanta que as notícias conhecidas acerca de conferências republicanas em São Luís datem já do derradeiro ano de 1889, nas quais, por vezes, manifestantes populares irrompiam, sobretudo ex-escravos, em defesa da monarquia e da Princesa Isabel, A Redentora ${ }^{6}$. Vale observar que no chamado Alto Sertão, porção sul do Maranhão, pouco integrado ao centro administrativo litorâneo até meados do século XX, concentravam-se as cidades e vilas de maior

importantes da política maranhense, ele deixou o cargo de professor para assumir a posição de Oficial de Gabinete de Dr. Cassimiro Dias Vieira Junior no ano de 1893. Mudou-se apenas para ocupar o lugar de diretor na Biblioteca Pública, cargo que assumiu interinamente em 1897 e como efetivo em 1898. Em termos de produção bibliográfica, Lobo, enquanto dirigia a Revista do Norte, destacou-se por suas traduções. Contam entre as suas produções o romance A carteira de um neurastênico (1903), além dos livros Positivismo e micróbio (1908), Doutrina transformista (1909) e Os novos atenienses (1909).

5 Os jornais maranhenses, sobretudo no ano de 1889, estão repletos de matérias que informam o processo de racialização do conceito de República. Um exemplo interessante é o modo como o fazendeiro Joaquim Castro, natural de Guimarães, congratulava seus correligionários pelo 15 de Novembro, expressando sua "tomada de consciência" republicana: "Fui conservador até o dia 13 de ano passado, quando libertaram os escravos. Logo que deu-se esse grande passo para liberdade, entendi que os brancos não podiam mais ser escravos da monarquia" ( $O$ Globo, $18 \mathrm{dez}$. 1889; grifos nossos). Para uma análise mais aprofundada do problema em outras partes do Brasil, ver Gomes (1991) e Albuquerque (2009).

6 Indignado com os protestos populares que irrompiam nas conferências republicanas que se realizavam no Hotel França em São Luís, o celebre poeta Joaquim de Sousa Andrade, o Sousândrade, replicava: "Por medo da República que não quer escravos, assinou-se o decreto popular da abolição; os lutadores abolicionistas eram todos armados pela República - e desgostosos depois vemos voltarem-se eles contra ela; até os que por ela foram libertos, tripudiando insensatos dão morras a República!... É a crucificação eterna dos salvadores" (Sousândrade, [1889] 2003, p. 2010). 
agitação republicana local ${ }^{7}$. Quando a Junta Provisória Republicana assumiu o poder, no dia 18 de novembro de 1889, instalou-se um clima de insegurança e repressão política:

Trêfega e irrequieta, longe de consagrar os ânimos, para que todos cooperassem no regime que se inaugurava, precedeu com exclusões, numa terra em que não passavam uma meia dúzia os republicanos históricos e procurou aproveitar-se da eventualidade que lhe pusera o governo nas mãos, para atirar-se à faina de formar elementos políticos que servissem aos planos de domínio de um só dos seus membros, que tinha pretensão a chefe do partido.

Acorde com esse pensamento, a polícia cometida na própria capital a pessoas as menos idôneas para exercerem-na, por conhecida falta de critério, tratou aí mesmo de se impor pelo medo, efetuando prisões a torto e a direito, castigando com palmatoadas as pessoas do povo d'um e outro sexo e raspando-lhe à navalha as sobrancelhas e metade do cabelo na cabeça.

Ninguém se reputava seguro numa tal emergência, em que a liberdade individual estava em perigo permanente. Não houve escala de violência que a junta não tocasse, chegando até a tentar deportações e fuzilamentos e isto sem que houvesse o menor indício que fosse de resistência a nascente forma de governo.

\footnotetext{
7 O historiador Alberto Ferreira, ao analisar as condições sociais de emergência do movimento republicano no Maranhão, destaca que "os sertanejos reivindicavam maior atenção dos governantes, mas estes priorizavam as regiões agroexportadoras objetivando equilibrar as finanças da província. Por outro lado, as constantes trocas de presidentes devem ter contribuído para que algumas solicitações não fossem atendidas. O certo é que o Alto Sertão pouco se beneficiou das medidas modernizadoras (navegação a vapor, estradas, engenho central, fábricas têxteis) implementadas na província na segunda metade do século XIX. Nesse contexto, foi o sertão um campo propício para a germinação das ideias republicanas. Seus partidários conheciam os modelos de República implementados na França e nos Estados Unidos. Porém, sua motivação maior era o federalismo, a busca de autonomia, como uma maneira de reação à hegemonia política da parte norte da província" (Ferreira, 2004, p. 214).
} 
A República, logo nos seus primeiros passos, sofrera, portanto, com aquele governo coletivo, a influência perniciosa de uma impressão verdadeiramente desgraçada, aliando-se seu advento na Província à prática de tropelias em ordem a gerarem no espírito popular a ideia de que o novo regime, em vez de garantir a ordem e os direitos dos cidadãos, fazia periclitar a primeira e investia contra os segundos (Godóis, [1904] 2008, p. 361).

As palavras de Barbosa de Godóis (1860-1923), terceiro vice-governador do Maranhão republicano, dedicado à tarefa de escrever uma História do Maranhão para o novo regime, demonstram que mesmo entre as classes dominantes os 29 dias do primeiro governo provisório foram vivenciados como um período de grande insegurança social. $\mathrm{O}$ recurso abusivo da violência policial, prisões e torturas criaram um clima de pavor e ameaça à liberdade individual.

138 Nem mesmo as mulheres escapavam das agressões justificadas como medidas necessárias à preservação da novíssima República. Tamanho autoritarismo fora em parte motivado pelo grande protesto de ex-escravos monarquistas, cerca de quatrocentas pessoas, em 17 de novembro, contra o jornal republicano $O$ Globo, propriedade de Paula Duarte, e que, no dia anterior, anunciara a derrocada do Império. Decretos de fuzilamento e deportação foram expedidos com o fito de intimidar a ação populista dos monarquistas junto ao povo. A contenda às portas do teatro São Luís, que virou um misto de fato, boato e finalmente piada, pertence a essa conjuntura turbulenta que marcou profundamente a memória política maranhense do advento da República como um período de terror e violência.

\section{Riso e melancolia / História e ficção}

O paciente leitor dessas linhas deve estar se perguntando a razão de tanto entretenimento com uma pequena anedota 
num ensaio que deveria ser dedicado a objetivar o tema da República nos contos de um desconhecido escritor negro maranhense cujo nome, até o presente momento, não foi sequer citado. É porque o então jovem Raul Astolfo Marques (1876-1918) escolhera justamente a referida anedota como tema do conto "O discurso do Fabrício", um dos seus principais escritos dedicados ao novembro mais decisivo da história política brasileira. Desse modo, temos um bom começo para enfrentar a questão proposta neste ensaio, acerca da representação da República brasileira na obra ficcional de Astolfo Marques.

O texto foi publicado em duas partes, nas edições de 16 de novembro e 1ํ de dezembro de 1903 da gazeta literária A Revista do Norte ${ }^{8}$. Na época, era a principal revista literária editada em São Luís, com duas edições mensais e circulação em Manaus, Belém e Teresina. O periódico era especializado em temas relativos à região norte do país e tentava reunir em suas edições escritores de suas principais capitais, publicando ensaios, textos literários e artigos que tratavam desde história e literatura até os problemas mais candentes de infraestrutura e integração nacional que ainda afetam o Brasil setentrional.

"O discurso do Fabrício" se adaptava perfeitamente à linha editorial de A Revista do Norte. Tal como indica a data da publicação (16 de novembro) e o subtítulo do conto (Recordações do 15 de Novembro), o objetivo do magazine era trazer aos leitores um motivo literário comemorativo dos catorze anos da novíssima República brasileira, com base na realidade local. Ressalte-se ainda que na qualidade de uma "recordação" o conto tinha a pretensão de ser uma

\footnotetext{
8 É significativo que Astolfo Marques tenha voltado a publicar o mesmo trabalho em sua primeira antologia de contos, intitulada $A$ vida maranhense (1905), e posteriormente o transformado, com poucas alterações, num dos capítulos de $A$ nova aurora (1913), novela histórica inteiramente dedicada às consequências sociais e políticas da Proclamação da República no Maranhão.
} 
reconstrução realista do passado histórico recente, dotada de caráter assumidamente ficcional.

Nesse sentido, é interessante notar que o autor dirigira a atenção dos seus leitores, desde o título, para o aspecto menos factual do conhecido episódio: o discurso que atraíra sobre si a ira do governo provisório republicano. Tal é o elemento central do texto. A construção do personagem Fabrício como um abolicionista e republicano de enorme popularidade na cidade São Luís, queridíssimo por seus amigos e companheiros de trabalho, convicto em seus ideais, se nos remete à vida e às convicções de Prazeres de Feitas, não sabemos, mas pretende indicar a representatividade que teria o discurso fictício do personagem. Senão, vejamos:

Entre os oradores inscritos [na festa da classe comercial em prol do novo regime republicano], achava-se o Fabrício, chefe duma das oficinas da Usina Maranhense, homem de 140 ilustração acima do vulgar. O seu nome, conhecido em todas as sociedades, era acatado reverentemente. O Fabrício fora presidente do Club Abolicionista e, na Usina, se os operários tivessem uma instrução regular, teria, inspirado pelo seu saber, conquistado um lugar proeminente, levantaria, se quisesse, um partido, tal a cega abnegação que por ele tinham. Acercava-se daqueles que, pela sua inteligência, o poderiam compreender e explicava-lhes, fundado na sua farta e variada leitura, a República, que ele considerava melhor forma de governo para um país. Pregava-a com uma eloquência em nada inferior a dos melhores tribunos. E dos que o podiam entender nessas prédicas, só um, o João Cadete, divergia de suas ideias. Todas as vezes que o fervoroso repúblico, terminava, na Usina, as suas "palestras doutrinárias", o Cadete respodia-lhe:

- Qual, seu Fabrício, se "isto aqui chegar a ser República”, algum dia, muita gente apanha bolo e você vai para cadeia (Marques, 1905, pp. 142-143). 
Fabrício é um "homem do povo". Na qualidade de chefe de uma das oficinas da Usina Maranhense ele se identifica, embora com posto mais elevado e instrução diferenciada, à formação do proletariado urbano livre do país nas duas últimas décadas do século XIX. O personagem também aparece ligado à causa mais popular de sua época: a libertação dos escravos. O narrador informa que Fabrício chegou a ser presidente do Club Abolicionista, ou seja, era de fato um "representante do povo", "levantaria se quisesse, um partido, tal a cega abnegação que por ele tinham". Noutras palavras, o personagem é uma figuração do desejo de transformação política e social.

O único traço impopular que molda a identidade de Fabrício é a militância republicana. Impopular no sentido de que a maioria dos operários não compreendia suas ideias. A República aparece como uma ideia distante do universo cultural dos trabalhadores, mediada por um conhecimento de valor intelectual. Tanto que para suas pregações doutrinárias o republicano de "instrução acima do vulgar" era seletivo, "acercava-se daqueles que, pela sua inteligência o poderiam compreender". Entretanto, ainda sim, havia quem não acreditasse que a República fosse um regime capaz de realizar suas promessas de igualdade social. "Qual, seu Fabrício, se "isto aqui chegar a ser República', algum dia, muita gente apanha bolo e você vai para cadeia".

Essa frase profética anuncia logo no terceiro parágrafo do texto o destino do herói. A drástica economia de meios termos para colocar o leitor a par da problemática central faz de "O discurso do Fabrício", nos termos de Julio Cortázar, um conto de intensidade ${ }^{9}$. A fórmula inventada por Edgar Allan Poe é assim resumida pelo escritor argen-

\footnotetext{
9 Para uma discussão mais aprofundada acerca das características formais do conto de intensidade ou conto clássico, ver Pontieiri (2001) e Gotlib (2002).
} 
tino: "No conto vai ocorrer algo, e esse algo será intenso. Todo rodeio é desnecessário sempre que não seja um falso rodeio, ou seja, uma aparente digressão por meio da qual o contista nos agarra desde a primeira frase e nos predispõe para receber em cheio o impacto do acontecimento" (1993, p. 124). Essa é a pretensão estética de Astolfo Marques. Deixo à crítica literária o veredito de se ele conseguiu ou não o efeito desejado. O importante aqui é saber que a narração pretende predispor o leitor para receber com intensidade um acontecimento "profético" que expõe a contradição entre os princípios republicanos de igualdade e a violência autoritária que concretizou a Proclamação da República na periferia do Império.

Não sem razão, findo o terceiro parágrafo com a frase do antagonista João Cadete, o autor nos conduz diretamente ao cenário do "discurso do Fabrício":

142 Assomando a tribuna, o Fabrício foi recebido por uma estridente salva de palmas, que rumorejou altissonante pelo abobadado edifício, ao contrário do que o auditório, superior à lotação da casa, fizera com os oradores que o precederam e que foram recebidos friamente.

Diante da estrepitosa manifestação que o povo lhe faz, o tribuno deixa transparecer comoção, dominando-se, porém. Fitando a enorme massa popular, que incessantemente o aclama, como que ele sentia o que ia de sincero nas constantes vivas aclamações.

E a multidão, de instante a instante, agita-se sofregamente; todos como que anseiam pela palavra do orador; sente-se que aqueles milhares de cérebros têm o mesmo objetivo, o mesmo desejo.

Faz-se, finalmente, o silêncio: e a palavra do orador, temida e querida, é escutada. Fluente, emocionante, carinhoso umas vezes, causticante outras, vai dominando o auditório, que compacto, se acotovelava. 
O povo, agora, mudo e quieto, sentindo vibrar a sua alma as palavras de Fabrício, ouvindo-o atentamente, embaladamente preso ao silêncio; aquele discurso, em que era feito uma verdadeiro libelo de acusação aos membros do governo provisório, era também o porta-voz de todos aqueles corações.

E quando o ardoroso orador compreendeu que tinha por si a grande massa popular e que, pela palavra, dominara essa avalanche de seres vivos e pensantes, perorou: Concidadãos! Essa forma de governo que ora nos felicita, de República só tem o rótulo! A República, como deve ser, ainda não a temos, pois os bolos estão chovendo nos postos policiais, e, cidadãos livres, como somos, nós, os brasileiros, assistimos ao degradante espetáculo de ver os nossos irmãos com as cabeças raspadas a navalha, a um simples aceno do Queirós! Abaixo os tiranos! Viva a futura República! (Marques, 1905, pp. 144-145).

A extensa descrição de Astolfo Marques retoma novamente o tema da representatividade política do povo. A relação que a "enorme massa popular" estabelece com Fabrício, único tribuno que não recebera friamente, é como público espectador. $\mathrm{O}$ autor descreve os usos sociais de uma tradição de mobilização civil da população urbana que fez história na propaganda abolicionista, uma vez que o teatro e seu repertório artístico conformaram a linguagem do ativismo antiescravista brasileiro (Alonso, 2010). Observe-se que Fabrício é capaz de tocar, nas palavras do narrador, os "cérebros", os "corações", a "alma" do povo, enfim, de dramatizar o conteúdo crítico de sua mensagem. Ele se "comove"; sua palavra "temida e querida" têm a medida certa do desejo de mudança daqueles que o escutam. Orador e público são uma mesma vontade política: a utopia adiada da República.

O discurso do Fabrício anuncia um sonho postergado. A República vigente é um rótulo. Um regime político incapaz 
de concretizar o livre exercício da cidadania. A crítica atinge o seu ápice na denúncia das torturas perpetradas pelo governo. Quanto a essas ocorrências, esclarece o historiador Mário Meireles que, quando se tratava de homens e mulheres pobres, a polícia, "além de prendê-los e castigá-los com palmatoadas, só mandava soltá-los com o estigma da cabeça raspada. Nisso, mais sofriam os negros, ex-escravos, que não deixavam de manifestar sua gratidão à Redentora" (1994, p. 113). Dado importante porque a humilhação da cabeça raspada infligida aos escravos fugidos havia se tornado, durante o gabinete imperial de Cotegipe, uma marca da repressão política escravista ao movimento abolicionista na corte (Needell, 2011, p. 250). O recurso aos símbolos do poder senhorial pelas forças da República era um recado explícito à população negra de que o novo regime era a velha tirania de sempre.

Esse tema é reafirmado no texto pelo infortúnio do personagem central na segunda parte do conto. Ao sair 144 do teatro São Luís em direção a sua residência, Fabrício se depara com um pelotão de policiais na porta de sua casa.

Preso, sem resistir, deixou-se conduzir placidamente à presença dos membros do governo provisório, cujos atos foram por ele, instantes antes, criticados acerbamente, violentamente.

A sua fisionomia, naquele momento, estava revestida da mais dolorosa impressão. Desditoso contraste! Uma hora antes, quando muito, o Fabrício recebia as unânimes aclamações dum povo, por intermédio de representantes de todas as classes sociais, e estava radiante de glória, enlevado, satisfeitíssimo, por ter cumprido um dos mais meritórios deveres - advogar a causa do povo. Agora, estava como que diante dum tribunal, mas não dum tribunal digno desse nome. Atiravam-lhe toda sorte de impropérios, insultavam-no baixa e torpemente, e ele, impotente para se defender diante daqueles espíritos neronianos, submetia-se, 
e, resignadamente, ouvia tudo. Ainda tentou justificar-se, dizendo timidamente:

- Eu pensava que a liberdade da palavra me seria mantida, como cidadão que sou...

- E tu ousas falar em liberdade, por ventura?! Atalhou encolerizado um dos governantes.

E o Fabrício, o "arrojado que tão atrevidamente ousara criticar os atos do governo", chamando para este a ira e clamor públicos, foi mandado levar a prisão, ficando incomunicável, como se fosse réu de crime nefando (Marques, 1905, pp. 146-147).

Agora nossa anedota converteu-se em literatura ${ }^{10}$. Mas desta vez o riso sede lugar à melancolia. No lugar do humor emerge o senso de uma perda social e humana irreparável. "A sua fisionomia, naquele momento, estava revestida da mais dolorosa impressão". O autor reinventa a cena da humilhação do tribuno republicano com uma dramaticidade algo patética. Fabrício é preso, insultado e humilhado pelos oficiais e membros do governo provisório justamente por sua

${ }^{10} \mathrm{Em}$ A nova aurora, reescrevendo o texto dez anos depois, o autor conserva mais elementos das versões conhecidas do episódio, mas acresce trechos inteiramente novos : "Atiravam-lhe toda a sorte de impropérios, insultavam-o, baixa e torpemente; e ele, impotente para se defender diante aqueles espíritos neronianos, quedava-se submisso à resignação de tudo ouvir. Por fim ele ainda tentou justificar-se, dizendo timidamente: - Eu pensava que a liberdade seria mantida, como cidadão que sou... - E $t u$ ousas, por ventura falar em pensamento e liberdade?! Atalhou-o, encolerizado, um dos do Provisório, que assumira a posição de inquiridor: Pensar!... Liberdade!... Se me definires estes dois vocábulos, prosseguia o interlocutor, deixar-te-ei ir em paz! Mas o democrático operário resolvera de si para si nem mais um murmúrio cair em sua defesa. Então, o verberante tomado dum tom impetuoso e forte para com o detido, fraco e indefeso, atirou-se a ameaça, num flamejamento de doutrina perante seus colegas da Junta e do oficial comandante da escolta. - Resolveste, então, avocar a tua mui insignificante pessoa um suposto direito de açular seus parceiros contra as instituições vigentes, empregando, para isso, a astúcia de decorar trechos de Castelar, José Bonifácio, Nabuco e mesmo meu, esmiuçar anelectos, para acompanhar os oradores hodiernos na ênfase, como na doutrina?! Pois fica sabendo que a Junta vai considerar-te bêbado; e, como tal, irás para a cadeia pública" (Marques, 1913, pp. 114-115). 
capacidade de representar o povo, pela pureza de seus ideais republicanos. "Agora, estava como que diante dum tribunal, mas não dum tribunal digno desse nome". A contradição política que gera o infortúnio do personagem espelha a iniquidade da ordem autoritária: "Viva a futura República!".

Mas as diferenças entre a anedota que virou piada e o conto não param por aqui. O sentido do diálogo entre a autoridade governamental e seu crítico é inteiramente modificado pela oclusão da linguagem racial. Astolfo Marques retira de cena "o negro", risível objeto de escárnio, e instaura, nesse mesmo lugar simbólico já consagrado pela memória, o cidadão. Onde ouvíamos apenas a frase "Eu pensava...", escutamos agora: "Eu pensava que a liberdade da palavra me seria mantida como cidadão que sou..." e onde tínhamos "Já viste negro pensar?”, temos então: "E tu ousas falar em liberdade, por ventura?!”. Ao escárnio racial 146 sucede uma cidadania aviltada. O problema negro torna-se o desafio político da liberdade.

Nesse ponto o texto transforma-se numa teia inextricável de literatura, memória e história. O diálogo entre o conto e a anedota torna ainda mais equívoca a relação entre ficção e realidade histórica. É nos silêncios de uma memória coletiva avalizada e comprometida com o processo de dominação que o autor coloca sua voz. O realismo começa exatamente no lugar em que a história é puro esquecimento. $\mathrm{O}$ efeito de realidade produzido no texto deve menos ao dado factual que as esperanças frustradas do nosso passado coletivo. Para Astolfo Marques a verdade está no fictício "O discurso do Fabrício”.

Mas por quê? A crônica "A última sessão", também publicada pelo autor em 1903, pode nos ajudar a esclarecer a questão. O cenário agora é a Câmara Municipal de São Luís, e o problema, a adesão política conservadora ao 15 de Novembro. Segue o texto na íntegra: 
Na estação telegráfica e numa das janelas da redação d' $O$ Globo havia sido afixado um boletim anunciando a organização, no Rio, do governo provisório bem como as medidas tomadas a respeito do embarque para Europa, no vapor Alagoas, do monarca recém-destronado.

A Câmara Municipal, composta de conservadores, na sua maioria, recebera a notícia como se fosse um maná vindo do céu. Excelsamente transportados de alegria, os seus membros, pouco se importavam que se lhes exprobassem de não confraternizarem com os líderes ajudando-os a sustentar o trono baqueante. Menos ainda ligavam aos que lhes acusavam de não ter fé monárquica, pois, consideravam: não fora essa monarquia, agora por terra, que promovera a libertação dos cativos, sem indenização? Era azado o momento da desforra, e a ninguém mais do que aos vereadores, dizia um destes, compete como representante dos municipais, soltar o grito de adesão. E opulentamente trajados, dirigiram-se a casa do vereador presidente, que, ouvindo-os religiosamente, concordou com os seus considerandos e fez convocar incontinente uma sessão extraordinária.

Reunidos os gestores dos destinos municipais, depois de serem sugeridos mil projetos e ideias, foi resolvido que a câmara ficasse em sessão permanente "aguardando ordem do governo provisório", passando a este um telegrama de congratulações em que cientificava o deliberado. Isto feito, retiraram-se o vereadores aos seus penates, ficando dois beleguins, prontos a primeira voz, substituindo-os na permanência.

Entardecera já. A cidade apresentava um aspecto bélico. Havia um presidente que não presidia, pois abandonando um posto de honra, abrigara-se na casa do chefe do partido em cujo expirara a monarquia; no largo do Carmo, trepado no Pelourinho, um orador concitava os magotes de monarquistas e curiosos que se revestissem da precisa calma 
para aguardar os acontecimentos; no quartel da tropa de linha tromitoava o sinal de reunir e logo depois o de avançar para o globo, donde haviam pedido garantias a fim de evitar o ataque do populacho desenfreado; um ex-deputado geral, conservador, colocara-se (e fora o único) ao lado de liberais que queriam dar cabo da vida dos redatores do jornal da ladeira do Viramundo. Nesta, já a aglomeração fervilhava. Numa atitude guerreira os motineiros atiravam chufas aos jornalistas "sitiados". E, à proporção que se ia avolumando a massa, crescia as vaias e as ameaças. Chegada a força foi recebida a pedradas. Os soldados, então, despediram flamejantemente sobre os "reivindicadores do trono" umas dezenas de baladas comblain, que zunindo entre os atacantes, os dispersou produzindo a morte em cinco, ferindo uns vinte, que passaram a posteridade como vítimas da abnegação por Isabel, a Redentora, e deram motivo ao Maranhão ser considerado a única província heroica que 148 resistiu a implantação do novo regime. Estabelecera-se a calma sendo já a noite alta. No dia seguinte, logo ao amanhecer, um telegrama vai ter a Câmara Municipal. Os beleguins correram presurosamente a chamar a seus postos os vereadores neorrepublicanos, que no acharam reunidos todos com exceção de um único que estava no interior. Para sessão ordinária não se reuniriam com tamanha presteza. Confortavelmente instalados nas suas poltronas, ao troar do tímpano, apresentavam na sua fisionomia uma atitude majestosa. E quem sabe se nos cérebros daqueles depositários dos poderes municipais a ideia da palavra "república" não se lhes apresentasse como sendo todos eles "majestade"!

E foi na antevisão de seguirem dali para o palácio governamental, então abandonado, que o presidente, tendo a pairar suspenso sobre a sua encanecida cabeça, ricamente emuldurado, um quadro de D. Pedro II, disse em voz alta e sonora: - Está reaberta a sessão! Em seguida, com um sorriso 
de satisfação, puxou do bolso o telegrama recebido, fechado ainda tal qual lhe entregaram o beleguim.

- Aqui temos a resposta, senhores; virá provavelmente seguida de altas e importantíssimas ordens, que, espero, todos cumpriremos de bom grado.

E, preparando-se para ler o despacho como se fosse um evangelho, cavalgou a luneta sobre o aquilino nariz e abriu-o auspiciosamente. Os vereadores olhavam sofregamente para aquele papelzinho, em que, contavam, viria escrita a palavra de ordem, isto é, a menção ao poder dos conservadores, metamorfoseados em republicanos da "gema". O presidente, com voz trêmula, procedeu a leitura do papelucho que fizera palpitar ansiosamente tanto corações. Dizia:

- Rosário, 17 de novembro de 1889.

CAMARA MUNICIPAL

\section{S. LUIZ}

\section{QUE HÁ DE NOVO?}

Ferreira Moura

Era o vereador ausente.

E foi a última que os vereadores monárquicos fizeram. Nesse mesmo dia a Câmara foi dissolvida, e o telegrama quem o recebeu foi já a Intendência nomeada para substituir a agremiação conservadora (Os Novos, 1903).

A presente crônica é o único texto antes do romance $A$ nova aurora no qual o autor articula uma visão propriamente histórica do processo que se desencadeou no fim do Segundo Reinado. Em linguagem direta, com ironia e laivos de intempestividade raros em sua obra, temos uma crítica contundente às bases políticas de adesão ao novo regime. Nos termos de Astolfo Marques, a República no Maranhão surge efetivamente como uma ideia fora do lugar. "Sua regra é outra, diversa da que denominam; é da ordem do relevo social em detrimento de sua intenção cognitiva" (Schwarz, 
2000, p. 19). Quem saberá ao certo se para os republicanos de ocasião, acossados pela Abolição na Câmara de Vereadores de São Luís, "a ideia de República não se lhes apresentasse como sendo todos eles majestade". Nesse sentido, a principal contradição do 15 Novembro é que seus defensores de primeiríssima hora visavam conquistar por intermédio do golpe político o "poder pessoal”, que a República deveria alijar em nome da cidadania.

O próprio perfil político daqueles que deveriam ser a vanguarda do progresso social era formado majoritariamente por elementos ligados ao partido conservador, quisto de ex-senhores raivosos, julgando-se traídos pelo governo monárquico nos seus direitos de propriedade privada devido à ausência da prometida indenização de suas peças humanas. A inautenticidade da posição dos "conservadores metamorfoseados em republicanos da gema” também é assinalada pelo seu notório descaso com a coisa pública: não 150 fossem as virtuais vantagens do evento em curso, "para uma sessão ordinária não se reuniriam com tamanha presteza".

O fato desses "neorrepublicanos" serem risivelmente destituídos do poder no dia seguinte em nome do governo que receberam como um "maná vindo dos céus" só reforça, nas tintas carregadas de desprezo com que o escritor os caracteriza, o quadro de alienação dos políticos maranhenses. Para Astolfo Marques, enquanto o povo foi para as ruas lutar em prol da causa monárquica às portas do principal jornal republicano da cidade, as elites dirigentes provincianas assistiram à queda do império bestializadas. "Havia um presidente que não presidia, pois, abandonado o posto de honra, abrigara-se na casa do chefe do partido onde expirara a monarquia”.

Nessa "lavagem de mãos" do poder público reside uma das principais razões para o "clima bélico" instalado dia 17 de novembro entre os jornalistas republicanos do diário $O$ Globo e os "magotes" monarquistas de ex-escravos na 
ladeira do Vira Mundo. Os mortos e feridos da multidão são a expressão brutal da exclusão social e política armada a reboque da nova ordem. Esta talvez tenha sido a revolta popular que mais impressionou Astolfo Marques ao longo de toda sua vida. É provável que ele possa ter sido uma testemunha ocular do acontecido. Se não, viveu o clima de perseguição perpetrado pelas autoridades republicanas com o fito de conter maiores protestos.

É essa "versão da história" que orienta a interpretação política da proclamação da República em "O discurso do Fabrício". Ao final do conto, quando nosso herói é finalmente solto, o personagem antagonista João Cadete o interpela sobre suas convicções políticas e lembra com debiques tê-lo alertado quanto a suas ilusões republicanas. Fabrício responde: "Ora, seu Cadete, isto são infelicidades da vida!". Dez anos depois o autor reescreveria esse fim: "O Fabrício esboçando um sorriso amargo, confessou que, francamente, não se estava a praticar a República por ele sonhada..." (Marques, 1913, p. 120).

\section{Tempos de incerteza}

Astolfo Marques publicou os textos "O discurso do Fabrício" e "A última sessão" em 1903. Um ano bastante singular em sua carreira de "escritor improvável". Na época, ele trabalhava havia cinco anos na modesta profissão de amanuense da Biblioteca Pública de São Luís. Ao mesmo tempo em que arrumava os livros, escrevia ofícios, preparava atas administrativas, estava imerso nos pequenos círculos literários que faziam daquela instituição um espaço privilegiado de sociabilidade. Era secretário-geral (amanuense) da agremiação literária Oficina dos Novos havia cerca de dois anos e, através do seu patrão e patrono, Antonio Lobo, diretor da Biblioteca Pública e editor da Revista do Norte, escrevia no suplemento desta última a coluna Apuntos Bio-Bibliográficos, dedicada as personalidades literárias da história maranhense. 
Embora em franca atividade, aqueles primeiros anos do novo século foram tempos de incerteza na ainda incipiente carreira de escritor. O período que compreende os anos 1900-1903 parece ter sido particularmente difícil para que o autor veiculasse seus trabalhos ficcionais em jornais como $A$ Pacotilha e O Diário do Maranhão - as mídias que conferiam maior visibilidade e notoriedade pública a seus articulistas e colaboradores em São Luís ${ }^{11}$. Mesmo na Revista do Norte, em que o autor possuía uma coluna fixa desde novembro de 1901, seus contos demorariam mais de um ano para aparecer e, ainda, com frequência bastante irregular. Dividido entre as tarefas de tradutor, biógrafo, folclorista e contista, indeciso no começo se assinaria Raul Marques ou Astolfo Marques, o escritor estava descobrindo o seu estilo como autor.

Não existem registros biográficos conhecidos sobre a vida do contista que antecedam seu ingresso na Biblioteca 152 Pública em 1896. Mas as escassas e genéricas informações disponíveis permitem entrever no ofício de amanuense, que tanto amargurou o escritor negro carioca Lima Barreto (1881-1922), a única via possível de acesso à vida literária para Astolfo Marques. Nascido em 1876, cinco anos após a Lei do Ventre Livre, não contou em sua meninice e juventude, pelo que se sabe, com o auxílio de um "padrinho" que lhe custeasse os estudos e auxiliasse sua família. Não se fala sequer no nome de seu pai nas notas e resenhas escritas sobre o contista. Silêncios e ausências significativos, uma

${ }^{11}$ Durante a pesquisa que realizamos nos jornais O Diário do Maranhão e A Pacotilha, referente ao período 1900-1918, na fase referente aos anos 1900-1903, apenas três trabalhos de Astolfo Marques foram localizados. No primeiro hebdomadário, trata-se do estudo intitulado "Odorico Mendes: apuntos biográficos", publicado nos dias 10, 12, 14, 19, 23 e 27 de dezembro de 1901. O único trabalho ficcional encontrado, "A procissão do Redentor", foi publicado em A Pacotilha dia 13 de novembro de 1903, portanto, apenas no fim daquele ano. Antes dele, o mesmo jornal publicou a crônica "O socialismo entre nós", no dia 1ํ de maio. Havia, no momento, pouco espaço para a visibilidade dos trabalhos ficcionais do autor nos jornais. 
que vez que o esforço e as "boas relações" de um pai e/ ou padrinho conformam a via de ingresso tradicional, indispensável aos pobres, no mundo da cultura letrada brasileira (Miceli, 2001).

A mãe sim é citada (Campos, 1935; Vieira Filho, 1951; Oliveira, 1976; Maranhão, 1976). Delfina Maria da Conceição Marques tinha como ofício os afazeres domésticos. Em suas Memórias inacabadas, o escritor Humberto de Campos a menciona nas linhas que dedica ao conterrâneo:

Uma figura houve entretanto, no Olimpo, que permitiu minha aproximação. Foi Raul Astolfo Marques, que se tornou conhecido, mais tarde, nas letras regionais, como Astolfo Marques, unicamente. Era homem de cor, de tez escura e embaciada, como a dos negros que sofrem do fígado. De estatura mediana, a fronte larga e fugidia, boca enorme e bigode ralo, possuía dentes enormes e brancos, que fazia aparecer a cada instante, sob a beiçorra da raça. Era amanuense da Biblioteca, mas desempenhava todos os misteres de servente: varria o salão, espanava as estantes, etiquetava os livros, enchia o filtro, molhava uma planta que havia à porta, e atravessava duas, três vezes, diariamente, a rua, para ir buscar na "Casa Transmontana”, um refresco para Fran Paxeco, Francisco Serra ou Antonio Lobo. Era, segundo me disseram, filho de uma preta, lavadeira e engomadeira. E a isso devia ele, talvez, a alegria de exibir, pondo em destaque o seu terno de casimira azul-marinho, cuidadosamente passado a ferro, os mais duros e lustrosos colarinhos do Maranhão.

Humilde e obscuro, mas infatigável no estudo e no trabalho, Astolfo Marques fez-se de tal modo indispensável aos homens brancos a quem servia, que, na organização da "Oficina dos Novos", eles se viram forçados a dar-lhe um lugar a seu lado (1935, p. 66). 
As palavras de Campos não expressam apenas o perfil do autor, mas dimensões do espaço simbólico em que ambos viveram. No relato, nota-se que a posição de Astolfo Marques como subalterno é qualificada não apenas pelo caráter dos trabalhos de baixo escalão que desempenhava, como varrer salão, espanar estantes, molhar plantas, ir duas ou três vezes pegar sucos para seus patrões etc., mas também racialmente: ele é o filho da preta engomadeira que servia aos brancos. É a própria qualificação pejorativa de sua corporalidade negra (tez escura e embaciada, beiçorra da raça) que confere inteligibilidade à baixa posição social do autor frente aos demais homens de letras do seu tempo.

O memorialista capta com perspicácia e preconceitos indisfarçáveis as relações assimétricas de servilismo e dependência nas quais o escritor negro estava enredado. Ele contrapõe com sutileza a origem social obscura e racialmente estigmatizada de Astolfo Marques com sua aparência sem154 pre elegante, seu famoso terno de casimira azul-marinho e o colarinho lustroso e benfeito. O retrato é grosseiro e ousado: o servente de tez escura e embaciada era daqueles que precisavam "mostrar os dentes" para sobreviver em meio aos brancos a quem obedecia.

As memórias de Humberto de Campos se remetem aos anos de 1900 e 1901, quando o mesmo era balconista da Casa Transmontana, nas imediações da Biblioteca Pública de São Luís. Naquela data, Astolfo Marques já tinha recebido sua promoção de contínuo a amanuense e auxiliar do diretor; entretanto, ainda desempenhava "todos os misteres de servente". As ambiguidades das funções do escritor em seu ambiente de trabalho, nas fronteiras entre um serviço manual e um trabalho que demanda as competências do letramento, são reveladoras das condições de subalternidade de um homem cujo corpo deslizava entre os significados da recente "liberdade dos negros". É o modo prático e existencial particular de como o contista vivenciou na sua 
carreira profissional e literária a frustração coletiva das consequências materiais e simbólicas da Abolição e da República para a população negra. No artigo "Intelectuales negros en el Brasil del siglo XIX”, focalizando os casos de André de Rebouças (1838-1898), Cruz e Souza (1861-1898) e Lima Barreto (1881-1922), Maria Alice de Carvalho nos apresenta um quadro coletivo:

Com efeito, a estagnação e o imobilismo brasileiros pareciam ser adversos para esses negros ou mulatos, sempre localizados perto da pobreza, seja por inserção social ou por afinidade. No entanto, podiam prever que a rejeição do ambiente institucional que permitia as posições que gozavam e, ainda, a direção que adotava a recusa da ordem - encabeçada por segmentos das elites - implicava um risco para eles. Portanto, as tensões próprias de sua inserção no mundo explicam não somente a busca de esquemas de pensamento que não naturalizassem o moderno, como também a resistência em aliarem-se às vertentes críticas dominantes no Brasil. Nesse marco, a operação intelectual possível implicava no elogio do dinamismo, mas sem a substantivação do que deveria gerar como consequência (Carvalho, 2008, p. 316).

Essa reflexão nos permite reler o conto "O discurso do Fabrício”. A imagem profundamente melancólica da transformação política de 1889 conjuga tanto crítica histórica como denuncia a estagnação das alternativas de modernização política e social. "Eu pensei que a liberdade da palavra me seria mantida como cidadão que sou..." afirma o personagem central na iminência da tortura e da prisão. Não se vislumbra qualquer alternativa de transformação social. "Isso são infelicidades da vida", arremata a personagem central do texto entre o sonho da "futura república" e a impotência esmagadora dos dominados. 
"Impotência", servilismo e dependência que calaram fundo na vida e obra de Astolfo Marques. Embora a faina diária da preta Delfina contra os tamboretes de água e o ferro à brasa provavelmente a colocasse em contato com a gente fina do Maranhão, como dissemos, não há registros de que suas redes de trabalho tenham assegurado uma infância de estudos para o pequeno Astolfo. $\mathrm{O}$ pouco que sabemos é que ele se dedicou às tarefas e aos trabalhos mais humildes como ser "moleque de recado", ajudando sua mãe nas entregas de roupa e também como serviçal. O escritor é sempre referido como autodidata no sentido forte do termo. O crítico Antonio de Oliveira (1976) destaca, com base na entrevista que o contista concedeu sobre sua trajetória ao jornal Anais dia 3 de novembro de 1910, documento hoje perdido, que o mesmo aprendera a ler sozinho. Uma habilidade intelectual preciosa, rara e decisiva na trajetória profissional de Astolfo Marques.

Vale dizer que, de acordo com o Congresso Interesta156 dual de Ensino, efetuado no Rio de Janeiro em 1921, anos muito avançados do momento ora descrito, computava-se para o Maranhão o percentual de $95 \%$ de analfabetos em idade escolar (Paxeco, 1922, p. 624). Nesse contexto, saber ler era não só uma qualidade distintiva como um privilégio de muito poucos. A leitura também era um pré-requisito para o exercício da cidadania, pois analfabetos eram proibidos legalmente de votar. Em 1896, Astolfo Marques ingressara na Biblioteca Pública de São de Luís como mero "vassoura" e, não fosse o esforço em conhecer as palavras, jamais teria conseguido a promoção ao posto de amanuense e também de auxiliar do diretor, dois anos depois. A alfabetização, ao mesmo tempo em que o possibilitou alargar suas expectativas para além da rota dos "trabalhados inferiores", "pesados" e manuais, a que se destinava o grosso da população negra na década que sucedeu a abolição, também o instalara numa instituição central para organização da cultura letrada no Maranhão. 
Não seria exagero dizer que Astolfo Marques estava no lugar certo e na hora certa. No fim do século XIX, a Biblioteca Pública tornou-se o principal espaço de sociabilidade intelectual da capital maranhense. Na verdade, um dos únicos, se excluirmos as instituições de caráter educacional recriadas ou refundadas na primeira década republicana, como a Escola Normal (1890), o Centro Caixeiral (1890), o Liceu Maranhense (1893), a Escola Modelo (1896) e a Escola de Música (1902). Tal período foi marcado por um processo de reestruturação administrativa que criou vários obstáculos institucionais à dinamização da cultura erudita no Maranhão. No prefácio ao livro $O$ Estado do Maranhão em 1896, escrito por José Ribeiro do Amaral, primeiro patrão de Astolfo Marques na Biblioteca, o escritor Pedro Nunes Leal, que vivera os "tempos gloriosos" da geração romântica, faz um balanço aterrador da cena literária regional:

A primazia nas letras, conquistada por este recanto das terras brasileiras, pelos maiores vultos da literatura nacional, si empalidece e obumbra-se, neste último quartel do século, parecendo viver apenas das recordações e da fama daqueles que sublimaram suas épocas e o transcurso da fulgurosa existência, nem por isso extinguiu-se e apagou-se de vez: - como todos os fenômenos da natureza, tem o entendimento os seus brilhos e os seus estados de repouso e descanso.

Se a uma época longa e feracíssima de espíritos enaltecidos, por virentes ornatos do cultivo intelectual, se aparelha e segue outra, somenos e estéril, o desmaio, as mais da vezes, não importa senão em um reflexo de outros fenômenos que incidem em todas as ordens da atividade humana, entorpecendo-lhe a marcha.

Em todos os ramos da atividade teve o Maranhão suas glórias, e glórias reais e fecundas: - na política, nos 
primórdios de nossa organização nacional, conquistou a palma dominando, pelos seus estadistas, o movimentoso cenário; - na produtividade do solo, foi celeiro abundantíssimo de todo o norte do país; - nas artes, equiparou-se as outras circunscrições administrativas; - nas ciências, teve Gomes de Souza, Lacerda, Frei Custódio Serrão; - nas letras, Gonçalves Dias, Lisboa, Odorico Mendes, Sotero, Henriques Leal, Serra, Trajano Galvão, Gentil Braga e tantos outros, que deram existência e luzimento a literatura nacional, ganhando na liça do entendimento as glórias imorredouras da fama, que não fenecem com a geração que teve a dita do seu convívio deles. Mas contentou-se com tão peregrinas entidades a ubertosa fecundidade desta terra de promissão, tão bem classificada Athenas Brazileira?

A organização econômica - fatal - que presidiu ao povoamento do país, a princípio, como colônia -

158 fazenda, e, depois, nação explorada pela escravaria, não podia deixar de trazer - dada a emancipação - abalo profundo nos elementos de trabalho e na própria vida da sociedade, resultando no meio econômico uma comoção geral que veio refletir em todos os ramos da atividade da nação, repercutindo pelos domínios da produtividade intelectual.

E, de feito, não podem as letras prosperar toda vez que, na vida de uma nação, se perpetua uma perturbação de caráter permanente, trazendo aos espíritos a dúvida, a família, o mal-estar.

Desaparecidos os luzeiros, que a felicidade relativa de uma época produziu, a que, imediatamente, se lhe segue sujeita, já, a uma ação deprimente de um cataclismo de ordem econômica, apresenta, como que uma solução de continuidade, sendo que as exceções que se destacam, vão fecundar novas regiões, onde a vida é possível. É o que se deu com o Maranhão! 
A felicidade relativa de que gozou durante o meio século de sua existência, como província do Império, fez brotar e desenvolver o seu espírito eminente, claro e fecundo, ganhando-lhe a palma e a sobrelevância no vastíssimo campo das letras: - com as dificuldades da vida vieram o êxodo e a carência de estudo.

Os poucos que dentro em si sentiram o alvorecer do talento demandaram as regiões bonançosas, onde as letras colhem louros e a cultura é premiada: daí o aparecimento, na Capital da Nação, dos Teixeira Mendes, Raimundo Correia, Coelho Neto, Azevedos, todos filhos do Maranhão.

Hoje, só de espaço e distanciadamente, surge, raro, um espírito perseverante e tenaz tentando vencer a atonia que amolenta a nativa fecundidade deste torrão abençoado e cheio de vida valente. Esses raros batalhadores, beneméritos da geração que passa, vão dando espaço a uma nova que bruxuleia no horizonte, já aureolada pelos raios prolíficos da democracia pura (Leal, 1897, p. III).

O depoimento de Pedro Nunes Leal é paradigmático. No último quartel do século XIX a tônica da reflexão maranhense sobre seu próprio universo intelectual se concentra numa indagação obsessiva sobre as razões da sua decadência, tema dileto de um punhado de estudiosos (Almeida, 2008; Borralho, 2000; Costa, 2002; Martins, 2006). Um problema especialmente relevante, por se tratar de um autor que manipula sua própria notoriedade no ambiente provinciano pelo fato de ter pertencido à influente geração romântica local que conquistou para aquelas longínquas paragens do Império brasileiro o epíteto de Atenas Brasileira. A nomeação expõe, parafraseado Rossini Corrêa (1993, p. 103), um modo da elite letrada "timbira" colocar-se na "selvageria" cultural das Américas protegida e distinguida pela cultura clássica europeia. Um constructo cultural que revela o impasse da geração fidalga pós-Independência, 
entre o passado colonial português e o futuro necessariamente brasileiro ${ }^{12}$.

Note-se que o já idoso lexicógrafo elabora uma espécie de "teoria da decadência". O desafio do texto, mais do que prefaciar um livro, é explicar como a sua bela "terra de promissão" que deteve a "primazia das letras pelos maiores vultos da literatura brasileira" pôde chegar ao final do século XIX à um estágio de "desmaio" e "esterilidade". Adotando o típico jargão científico pós-1870, explica Leal que, como "todos os fenômenos da natureza", tem a inteligência seus estágios de ascensão e declínio. Fato que pode ser observado na trajetória cultural maranhense comparando-se a "felicidade relativa de que gozou durante o meio século de sua existência como província do Império" e o seu presente republicano. Uma consequência "fatal" do impacto do processo de abolição do trabalho servil negro em "todos os ramos da atividade da nação, repercutindo pelos domínios 160 da produtividade intelectual”. Nesse sentido, a emancipação dos escravos, "trazendo aos espíritos a dúvida, à família, o mal-estar”, é apontada como a principal responsável pela decadência espiritual do Maranhão.

Esse aspecto é decisivo nesta análise. Ele revela o sentido conservador do ressentimento letrado às condições sociais de produção intelectual na Primeira República. Para amplos setores da elite, a Lei Áurea foi vivenciada como um ataque à tradição e à história maranhense ${ }^{13}$ : uma perspecti-

\footnotetext{
12 Esse é justamente o caso de Pedro Nunes Leal. Nascido em 22 de agosto de 1823, apenas dois anos após a Independência, e falecido dia 7 de novembro de 1901, formou-se em Direito na Universidade de Coimbra e atuou no Maranhão como fundador e diretor do colégio Instituto de Humanidades do Maranhão. Foi também tradutor, jornalista e lexicógrafo. Para melhores informações ver Meireles (1958, p. 31).

${ }^{13}$ Essa perspectiva teve vida longa no século XX. No livro História do comércio do Maranhão, de Jerônimo de Viveiros, o autor chega a afirmar que o 13 de Maio deixara o ex-senhor "atordoado pelo golpe que lhe arrancava parte do patrimônio, estarrecido diante da desorganização do seu trabalho, agora sem braços, com êxodo dos ex-escravos, que das fazendas partiam para a festa da redenção da raça" (1954, p. 557). A abolição seria, portanto, um desmerecido golpe daqueles que
} 
va diametralmente oposta àquela presente no texto "O discurso do Fabrício”. Com efeito, parte da amarga decepção dos grupos dirigentes locais com o novo regime, como quis sugerir Astolfo Marques em "A última sessão”, advém de sua ineficácia institucional para restabelecer, sem as "dúvidas" e o "mal-estar" assinalados por Nunes Leal, a legitimidade senhorial de outrora. Quem sabe, vale repetir com o escritor negro, "a ideia de República não se lhes apresentasse como sendo todos eles majestade".

Outro argumento importante que o gramático faz derivar do "abalo profundo nos elementos de trabalho e na própria vida da sociedade" é relativo aos próprios meios de exercício do labor intelectual. Ao descrever a geração de foros realista, naturalista, parnasiana e simbolista que sucede a sua própria, destaca que aqueles "poucos que em si sentiram o alvorecer do talento demandaram as regiões bonançosas, onde as letras colhem louros e a cultura é premiada”. $\mathrm{O}$ autor pretende denunciar, tomando com referência a capital fluminense, o lugar depreciado dos "homens de cultura" no Maranhão de fin de siècle. O fim da escravidão, "uma perturbação de caráter permanente", teria sido capaz de rasurar as linhas de distinção e prestígio cultural que conferia sentido nativo ao epíteto Atenas Brasileira. Ao contrário dos bons e velhos tempos de "antiguidade clássica", a atividade literária não é mais motivo de honra e glória. Algo um tanto contraditório, pois que a nova geração nasce "já aureolada pelos raios da democracia pura”, o novo regime republicano.

$\mathrm{O}$ dilema vivenciado pelos intelectuais tradicionais de São Luís é que, contrariando todas as expectativa de modernização social e de conquista de um lugar relevante para região no jogo político nacional, o advento da República

julgavam justa a "punição do escravocrata que havia no lavrador. Esqueciam-se porém que eles tinham deveres para com aquele trabalho, cuja evolução custara dois séculos e ingentes e perseverantes dos nossos antepassados" (1954, p. 557-558). 
expôs em todos os setores da vida social a fragilidade institucional do Estado para enfrentar a nova conjuntura governamental. De um modo geral, a própria região norte do país consolida-se como periferia da nação. No longo poema "Harpas de ouro" (1898), dedicado aos dez anos da proclamação do regime republicano, o poeta Sousândrade, primeiro intendente (prefeito) da capital maranhense durante o governo de Deodoro da Fonseca, expressa em duas estrofes amargas suas desilusões:

E eis minha casa, miniatura /

República: o pão... me dar / Pedras a Vitória, e doçura... /

Nessum maggior dolore, a olhar / Sorrindo à esperança, que ventura / Quão docemente a de chegar!

Armas com que fiz a república / Pontas voltaram contra mim / Antes deixasse a raça lúbrica / Em seu hediondo 162 chifrim (Sousândrade, 2003, pp. 440, 445).

A situação de penúria que marca os últimos anos de vida de Sousândrade é o exemplo mais radical de humilhação pública que assombrava a intelectualidade ludovicense. Tal como canta em seus versos, o significado da República se confundia com a sina pessoal de ser obrigado a vender as pedras dos muros de sua própria casa para ter o que comer (Williams, 1976, p. 6). "Armas com que fiz a república/Pontas voltaram contra mim”.

Também é significativo que uma das maiores frustrações do poeta na primeira década do novo regime fora a ausência de qualquer auxílio governamental, estadual e federal, ao seu projeto de fundação de uma universidade em São Luís. Fato que revela o total descompasso entre as expectativas dos intelectuais da terra, que viram no 15 de Novembro uma alternativa para a dinamização da cultura erudita regional, e as oportunidades políticas concretas 
para realizá-las numa época em que as chances reais de consagração literária nacional passaram a estar decisivamente condicionadas à saída do Maranhão. Antonio Lobo, em $O s$ novos atenienses (1909), livro que tem por objetivo narrar a história da geração de Astolfo Marques, descreve os impasses e alternativas da juventude letrada naquele fim de século:

Uma grande parte dos cavaqueadores, terminando o curso do Liceu, ausentaram-se do Estado, rumo das academias, onde se foram diplomar; outros trocaram inteiramente as veleidades literárias do começo, pelas ocupações burocráticas, mais rendosas e compensadoras; a morte arrebatou diversos; e os pouquíssimos que se mantinham fieis aos credos antigos, recolheram-se ao silêncio, feridos pelo desânimo e a deserção dos companheiros, aguardando, talvez, épocas mais propícias para voltarem a luta (Lobo, [1909] 2008, p. 42).

Eram precisamente essas alternativas "mais rendosas e compensadoras" da burocracia estatal que estavam completamente fora do horizonte de Astolfo Marques naqueles começos dos anos 1900. Diga-se de passagem, as melhores colocações profissionais estavam necessariamente atreladas ao carisma de manipular o conhecimento da cultura letrada durante toda a Primeira República (1889-1930). Os bancos do elitizado Liceu Maranhense eram a única via para as prestigiadas Faculdades de Direito e Medicina sediadas em Recife, Salvador, Rio de Janeiro e São Paulo. Se o autodidatismo servira para ultrapassar a linha negra dos serviços exclusivamente manuais, por outro lado, não autorizava maiores expectativas de expressão e reconhecimento público. Muito pelo contrário. Após cinco anos de trabalho na Biblioteca, a posição ambígua de "servente-amanuense" representava também o limite estagnado de sua carreira profissional nos órgãos do Estado. 
É nesse contexto, mais precisamente entre os anos de 1900-1904, que a problemática da República surge com força nos seus contos. Um tema que marcaria indelevelmente toda sua obra. Uma parte significativa da literatura produzida pelo escritor negro maranhense poderia ser entendida como uma tentativa sistemática de interpretar os significados da transformação política de 1889 para o povo. O tema comparece ao longo de toda a sua trajetória intelectual em contos como "Abnegação" (1901), "A última sessão (1903), "O discurso do Fabrício" (1903), "A opinião da Euzébia" (1904), "De coroa e barrete" (1908) e "Reis republicanos" (1916). Resta dizer que A nova aurora (1913), seu único romance, é inteiramente dedicado à descrição dos primeiros meses de implantação do regime republicano. A escolha literária é orientada por um ambiente cultural cada vez mais insulado e periférico no jogo político oligárquico nacional de hegemonia paulista e mineira, mas também 164 mediada por relações de dependência socioeconômica e subordinação racial.

\section{Modernidade republicana e cidadania negra}

A essa altura o leitor deve ter notado o interesse especial desta análise pelos primeiros contos de Astolfo Marques sobre o regime republicano na periferia do Brasil. Não se trata apenas de demonstrar a pertinência originária do tema para a conformação do projeto literário do autor, mas assinalar o enraizamento dessa escolha na problemática nacional sobre a real capacidade da pátria enquanto uma sociedade moderna, capaz de romper os laços com o passado colonial e escravocrata.

Os eventos sangrentos dos primeiros quinze anos do novo regime (separatismo sulista, 1893-1895; Revolta da Armada, 1893; Insurreição de Canudos, 1896; Revolta da Vacina, 1904), revelaram o fracasso da ação política em enquadrar a população brasileira nos modelos liberais vigentes 
nos países europeus (Carvalho, 1987). A estruturação de oligarquias estaduais profundamente patrimonialistas colocou na ordem do dia a questão dos limites do interesse privado na condução da coisa pública. Por outro lado, a vigência do racismo científico nas principais faculdades do país alimentava o medo e a crença de que todo esforço de progresso nacional pudesse esbarrar na força degenerativa do sangue africano que inunda o corpo colorido do povo brasileiro. Numa frase: imperativos como a existência de um povo incivilizado, a corrupção política desenfreada, a força da luta das raças decidindo silenciosamente o destino das nações, eram imagens de um mundo incapaz de abrigar uma identidade nacional a um só tempo moderna e genuinamente brasileira.

Para ser breve, e não incorrer na falta de recontar uma história hoje bem documentada, preciso apenas reafirmar que a literatura foi o palco privilegiado dessas angústias. É nesse espírito que obras de fôlego como Os sertões, de Euclides da Cunha, e Canaã (1903), de Graça Aranha, tentaram levar às últimas consequências expressivas a interrogação sobre o dilema de uma modernidade nacional, nas quais as fronteiras entre a civilização e barbárie se perdem na diversidade cultural e biológica de uma gente e uma terra vastas e ignoradas ${ }^{14}$

\footnotetext{
14 "No Canaã, com efeito, a vinculação moral com a terra é apenas um contraponto para a figuração alegórica do eldorado dos trópicos que faz do romance um espaço aberto à ação dos caldeamentos de toda sorte [...]. Ao contrário de Os sertões (1902) em que a ausência de unidade da raça se constitui num tema para consciência de nosso atraso, a convivência no Canaã entre colonizadores e colonizados, a pretexto da ocupação da terra inóspita, prescinde dos apelos da pátria. 'Isso a que chamamos nação não é nada', diz Mikau a um nativo exaltado. 'Aqui já houve talvez aparência de liberdade e de justiça, mas hoje está tudo acabado'. Do ângulo do colonizador, a noção de que o Brasil é um cadáver que se decompõe para servir de pasto à ação dos mais aptos representa no fundo uma penitência que põe a nuas consequências de nossas mazelas: esbulho burocrático, justiça precária, desvirtuamento da cidadania. Basta lembrar que, para o colonizado (um Brederodes, um Pantoja, um Itapecuru), a descrença na possibilidade de preservar a própria identidade transforma a civilização num sentimento de perda que aguça a vontade de resistir, aproximando-se da atitude crítica de Euclides da Cunha, então preocupado em defender o homem da terra como se fosse a rocha viva da própria raça” (Prado, 2004, p. 36-37).
} 
Nesse sentido, é interessante observar que o primeiro indício da longeva reflexão de Astolfo Marques acerca da República também tenha começado por Canudos. O conto "Abnegação" (1901) narra o infortúnio de dois soldados, pai e filho, no combate contra o arraial de Antonio Conselheiro. Tal como o título do texto torna previsível, os protagonistas da estória irão morrer em nome da lealdade militar à República, mediada pelo amor paternal e filial de um pelo outro. Ao fim dessa curta estória, o velho recebe a notícia de que perdera a mulher e precisa voltar para São Luís e honrar sua casa enlutada. Desiste a meio caminho e retorna, passando à frente do batalhão republicano e termina, por engano, cravado por balas do seu próprio exército. $\mathrm{O}$ ímpeto do jovem para salvar o pai o torna presa fácil para os jagunços, que o alvejam com o velho ainda nos seus braços. Aquela guerra e a abnegação dos bravos não tiveram, portanto, qualquer sentido. Mas não nos interessa aqui o desfe166 cho e sim o que ocorre à mente dos combatentes durante o percurso até o sertão baiano:

Ao receber o adeus de todo o povo maranhense, todavia, não choraram. Não eram soldados da pátria? Para que se fizera o soldado, senão para morrer defendo-a?

E seguiram. Passaram pela terra de Alencar, pela de Deodoro e de Floriano e chegaram à de Gregório de Matos. Cairu, e tantos outros onde demorariam ainda alguns dias à espera dos outros regimentos que faziam parte da sua divisão.

Neste ínterim campeava, em forma de verdade, o boato. Assim era que Gaston de Orleans percorria o arraial dos fanáticos, animando-os e auxiliando-os monetariamente; Isabel, a Redentora, consagrada santa pelos jagunços, e com um poder milagroso sem igual, impedia que chegassem vivos às cercanias do local conflagrado, os soldados da República; Antonio Conselheiro pregava a monarquia; os 
comboios de viveres não chegaram a vencer metade do caminho, e a fome chegara.

Mas o velho e o moço tinham fé na virtude da raça e na vitalidade do país. Poder-se-ia duvidar disso, quando do solo dos antepassados se erguia tanto devotamente e tão boa vontade? Mas conjecturavam, não são brasileiros também esses que lá estão fanatizados? (Os Novos, 1901).

A questão que Astolfo Marques faz pairar na cabeça de seus combatentes é a perturbação de uma época. Ela carrega toda contradição política da descontinuidade entre o nacional e o popular e o fascínio intelectual caracteristicamente moderno de interrogar na alteridade sua autenticidade cultural. Os grandes personagens da chamada literatura "pré-modernista" devem muito de seu valor expressivo à intensidade com a qual formalizaram esteticamente essa problemática. Nela reside a "alma encantadora" que João do Rio encontrou nas ruas sujas, presídios, carnavais e subúrbios cariocas. Ela também dita a inocência cega com que Policarpo Quaresma se convence da grandeza das "coisas brasileiras" e molda seu triste fim, na pena de Lima Barreto. A vitalidade, miséria e estigma com que Aluízio Azevedo desenhou seu cortiço. O deslumbramento de Euclides da Cunha com o infinito verde-amazônico e seus seringueiros às margens da história e da linguagem. Tem-se o drama de uma identidade coletiva que, para ser moderna e original, precisa fundar sua face em rostos negros, desdentados e famintos.

O problema não é apenas que a resposta à questão do escritor maranhense seja amargamente afirmativa mediante as expectativas de civilidade europeia e higienização social que alimentava a ideologia das classes dirigentes ${ }^{15}$. Mas que

\footnotetext{
15 Até mesmo porque essas ideologias não foram únicas e nem incontestes. "Em sentido complementar, intelectuais como Afonso Arinos, Mello Moraes Filho, Alexina de Magalhães, Lindolfo Gomes, Alberto Nepomuceno, dentre muitos outros,
} 
o seja precisamente através do "fanatismo" dos seguidores do Conselheiro, na crença do poder da Santa Princesa Isabel de redimir todos os sofrimentos e impedir os soldados da República de chegar ao arraial, pela assombração e "auxílio monetário" de Gaston de Orleans aos jagunços, através da autonomia inventiva e palpitante de valores culturais populares contramodernos.

Essa experiência de choque transforma em problema a constituição da identidade nacional, por meio da oscilação entre a identificação etnológica e distanciamento etnocêntrico e pela dificuldade em estabelecer, através de positividades e negações, as margens do seu próprio campo cultural (Ventura, 1990, p. 138; grifos do autor).

É essa dificuldade para estabelecer a linguagem oficial do imaginário coletivo que tanto caracteriza a sensibilida168 de artística e intelectual brasileira na Primeira República que adquire uma entonação singular na produção cultural popular e erudita de indivíduos racialmente subalternizados na ordem pós-escravocrata.

Esses intelectuais, geralmente jornalistas, artistas, artesãos, literatos, foram também os porta-vozes de um sentimento popular que ia além da aspiração por respeito, igualdade de tratamento e de oportunidades que medrava nas camadas médias urbanas, majoritariamente brancas, geralmente de origem imigrante [no Sul do país]. Esta outra aspiração a que me refiro era a de livrar-se do

interessados na valorização dos costumes populares, não podem mais ser tidos como exceção. Na Primeira República, diversos agentes sociais, como intelectuais, professores, maestros, músicos populares e o variado público do teatro e das festas populares, formado por setores médios e trabalhadores, experimentaram, em meio a muitos conflitos, a construção da nação - e também da nação republicana - em termos culturais" (Gomes e Abreu, 2008, p. 13). O presente ensaio seria pouco inteligível desconsiderando essa perspectiva, não? 
preconceito de cor e do estigma da escravidão pensando a nação brasileira como mestiça.

A aspiração por igualdade de tratamento e de oportunidade, portanto, nesses segmentos urbanos fundia-se, com um ideal de fraternidade e de solidariedade nacional, que pensava crioulos, pardos e mestiços como simplesmente brasileiros (Guimarães, 2010, p. 16).

Nessa perspectiva, a descoberta analítica do sociólogo Guerreiro Ramos ao desconstruir nas ciências sociais o então chamado "problema do negro", deslocando-o para indagar a formação do sujeito político moderno no país - "o negro é povo, no Brasil” (1995, p. 200; grifos nossos), afirma o autor -, adquire um campo de investigação renovado ${ }^{16}$. Com efeito, intelectuais negros como Lima Barreto, Nascimento Moraes, Hemetério dos Santos, Manoel Querino, dentre outros, fizeram de conceitos-chave do vocabulário político da modernidade ocidental como "povo", "nação" (mestiça) e "cidadania", a linguagem primordial com a qual expressaram sua negritude; o enraizamento social e cultural desses indivíduos nas expectativas políticas dos ex-escravos no período pós-abolição, nos silêncios entre certas anedotas e alguns contos. Noutras palavras, o que a pergunta de Astolfo Marques sobre as fronteiras e as tensões entre o nacional e o popular nos permite investigar, de forma tanto mais visível por se tratar da periferia do país, é o horizonte nativo da luta social na qual essas escolhas tornaram-se viáveis.

Em "A opinião da Euzébia" o autor percorre essas tensões de forma profundamente engajada. O conto, publicado no dia 1ำ de janeiro de 1904 na primeira página do

${ }^{16}$ Como esclarece Joel Rufino dos Santos: "Os estudo sobre o negro e a questão racial avançaram muito anos após sua morte, é verdade, mas não o bastante para superar o duplo paradoxo em que Guerreiro Ramos se debateu: não há raças, mas há relações raciais; e negro é povo, mas há negritude e não povidade” (1995, p. 26). 
jornal A Pacotilha, engrossava o caldo dos descontentes com a política sanitária no Maranhão. O flagelo da peste bubônica assolava São Luís desde fins do ano anterior, e revelava assim que a capital maranhense continuava a mesma cidade suja e endêmica dos tempos imperiais ${ }^{17}$. De acordo com o relatório A peste no Maranhão (1904) escrito pelo médico Victor Godinho, convocado de São Paulo para reestruturar o serviço de saúde dada à inépcia local, mais de 10 mil pessoas se refugiram no interior o estado temendo a infecção. Ademais, o quadro do serviço hospitalar era calamitoso:

O pessoal inferior era pequeno para cuidar de tão grande número de enfermos e não tinha a mais pequena noção do direito que tem os doentes ao bom tratamento no hospital. Eram os próprios doentes que procuravam a água, o leite e o remédio de que precisavam, ou eram seus vizinhos convalescentes, que lhos ministravam. Não havia horário para distribuição de dietas e refeição dos doentes, nem tão pouco para as refeições do pessoal. Muitos doentes faziam acompanhar-se por pessoas da família quase sempre de sexo diferente, marido e mulher, pai e filha, irmão e irmã etc., de sorte que não havia nas enfermarias separação de sexos:

\footnotetext{
17 "É necessidade por todos reconhecida o estabelecimento de um serviço regular de limpeza da cidade, que no respeita ao asseio das ruas, praças e praias, em que imundícies se amontoam, quer no atinente a remoção do lixo das habitações que ou permanece no interior delas, comprometendo a saúde dos que nelas assistem, ou jaz atirado horas e horas nas calçadas, oferecendo aos transeuntes um espetáculo repelente e envenenando o ar, que eles respiram, quando os cães não se lembram de espalhar pela via pública os mais abjetos detritos ali depositados. E nada se faz no sentido quer de melhorar os calçamentos que o exigem, quer de estabelecer um serviço de imediata necessidade pública, como é esse da limpeza e asseio da cidade ao passo que se cuida de embelezá-la! E as consequências do abandono em que é deixado semelhante serviço, aí temos na invasão da terrível epidemia que atualmente nos visita, e vai tomando as mais pavorosas proporções, devido a nada mais que asseio da cidade e das elementares medidas pela sua higiene, e a falta de ação enérgica quer do poder municipal, que do governo do Estado, que têm revelado a mais completa inaptidão para o desempenho dos árduos deveres que em tão difícil emergência lhes incumbiam" (A Pacotilha, 8 jan. 1904).
} 
- as enfermarias de mulheres tinham vários homens que acompanhavam seus doentes e nas de mulheres dava-se a recíproca. Não era possível haver ordem em tais condições. Os doentes graves, os convalescentes, os moribundos, e os são ocupavam promiscuamente as mesmas salas. O próprio isolamento dos doentes era uma coisa inteiramente virtual. Quem queria ter notícias seguras de seus enfermos procurava ir vê-los mais de perto, se amor que lhes tinha fosse maior que o medo da peste. A entrada no hospital não era inteiramente franca, mas pouco faltava para o ser. Pessoas estranhas ao serviço chegavam as muitas das janelas casas isoladas, trocavam objetos com as pessoas de dentro e demoravam-se o tempo que lhes aprouvesse, não obstante existir junto do hospital um corpo de guardas incumbido de manter o cordão sanitário (Godinho, 1904, pp. 10-11).

O médico paulista descreve em tintas carregadas de moralismo e zelo técnico uma realidade promíscua e aquém de quaisquer noções de direito no tratamento da vida. $\mathrm{O}$ fato de os próprios doentes serem responsáveis por si mesmos dentro do hospital ilustra a afinidade violenta entre a inocuidade dos serviços públicos, o tratamento patrimonial de bens estatais e a clivagem social da cidadania. Nesse ponto, sobre os recursos referentes a compra de vacinas haviam denúncias de que

os vapores chegam e ou nada trazem - a não ser as vacinas a serem recebidas particularmente pelo governo, segundo se disse, para justificar a sua distribuição pelos amigos particulares - ou o que trazem é em quantidade tão insignificante, que mais parece um escárnio a esta população (A Pacotilha, 13/01/1904).

Mesmo para Victor Godinho, que identificou na desordem da Secretaria Higiene uma prova da "indolência", "fal- 
ta de ambição" e "pouca dedicação ao trabalho" daquela gente do norte, "apesar dos bons exemplos que eram dados pelos desinfectadores de São Paulo, corretos zelosos e cumpridores de ordens e do dever" (1904, p. 29), era chocante a desigualdade dispensada ao tratamento de ricos e pobres em plena endemia. O Hospital Português mantinha uma casa de isolamento, cobrando a diária de $10 \$ 000$ réis e, por vezes, ainda requeria os poucos médicos e enfermeiros do setor público para tratar seus doentes de estirpe. Registra com ironia no relatório: "19 de fevereiro tive de mandá-las (enfermeiras paulistas) para uma das casas junto hospital a fim de tratarem um doentinho de classe. Aí estiveram em serviço até o dia 25” (1904, p. 31).

Com efeito, parte da grande atenção pública despertada pela peste bubônica em São Luís se deveu ao fato de a epidemia ter atingido as classes mais abastadas, uma vez que os surtos de doenças como lepra, beribéri, tuberculose, res172 ponsáveis pela maioria dos óbitos na população da cidade, nunca alarmaram as autoridades competentes (Almeida, 2004, p. 242). Mas o momento político também era propício para transformar a questão da higiene no crivo da boa ou má política pública. O governo do presidente Rodrigues Alves (1902-1906) elegera o combate as epidemias e o "problema sanitário" - que incluía a presença de mendigos, moleques de rua, habitações populares, e cortiços nas áreas centrais das capitais brasileiras - como uma das principais metas do seu mandato. Para tal, compôs uma poderosa comissão chefiada pelo famoso Dr. Oswaldo Cruz para desenvolver essa "política científica” que teve na Revolta da Vacina, em fins de 1904, sua consequência mais trágica (Sevcenko, 2010). Portanto, quando a peste bubônica devassava a capital maranhense a saúde pública era um problema político central no país ${ }^{18}$.

\footnotetext{
18 Portanto, tem-se uma arma política eficaz de oposição ao governo maranhense no contexto da peste: "O público é testemunha de como, esquecendo fundos res-
} 
A publicação do texto "A opinião da Eusébia" é parte dessa conjuntura nacional de radicalização política do problema da higiene pública, tensionada no Maranhão pela eclosão da peste bubônica. Mais uma vez, trata-se do típico conto clássico no qual é narrada uma história em primeiro plano, cifrando nessa um segundo relato, que surpreende o leitor ao emergir como tema central de toda narrativa (Piglia, 2004, p. 89). É assim que, nesse caso, a história do encontro fortuito de duas grandes amigas que não se viam há algum tempo converte-se no relato do flagelo da peste nos subúrbios de São Luís. Observemos inicialmente a narrativa dessa amizade apresentada em primeiro plano ao leitor:

- "Assim minha comadre, depois que seu Benzinho Mendes lhe deu a sorte grande, já ninguém tem licença de lhe por os olhos", dizia Euzébia das Carneiros à Libania, de quem era além de amiga e patrícia, comadre de fogueira, pois embora levassem vida airada, nenhuma havia concorrido com uma só unidade para aumentar os algarismos da estatística da população. Eram naturais de Codó, escravas das Carneiros, tendo vindo pra capital por intermédio do Caixa d'óculos, que as vendeu ao capitalista Fagundes, o qual, na antevisão do aceleramento com que se aproximava a extinção do elemento servil, as libertou e outras suas escravas juntamente, rendendo-lhe o ato de filantropia um Hábito da Rosa.

A Eusébia, rapariga ainda moça, vivia alugada como cozinheira, em cujo ofício era exímia; gostava de dormir em casa dos patrões, não só melhor esquivar-se de "meter-se

sentimentos e calando radicais divergências que nos separam do governo do Estado, procuramos desde o começo da epidemia que nos flagela, prestigiar os atos do poder público tendentes a debelá-la. [...] Mas tudo tem limites: a passividade absoluta só fez para natureza bruta; e é exatamente esse grande princípio que nos faz agora romper com todas as considerações para denunciar o governo do Estado como responsável pelo desenvolvimento que vai tendo a terrível epidemia que tantas vidas já tem ceifado" (A Pacotilha, 13 jan. 1904). 
com baralhos", o que nenhum lucro dava, como também para estar a par das novidades, não morria lá de amores pelos homens, apesar de sua corpulência bem formada e dos seus fartos quadris.

A Libania, mulata cujo corpo era de feitura semelhante ao da sua parceira, gostava de viver amasiada, e nessa vidinha era notável a sua predileção pelos Manueis, O Manuel Grande, a quem Deus haja, o Manuel Romeu, o Manuel Pimenta, o Manuel Bem-Servido, o Manuel Pichoso, o Manuel Rabada e parece que até os dois Manezinhos, todos a tiveram como apaixonada. Ultimamente amancebara-se com o Manuel Casimiro, e morava lá pras bandas do Filipinho; vinha à cidade uma vez por outra, não deixando, em cada uma dessas excursões de visitar a comadre. E como já fizesse muito tempo que não dava o ar da sua graça, foi que a Eusébia, que vinha da praia do Desterro com uma cambada de peixes no balde, fez aquela observação, ao encontrar-se

174 com a Libania, numa manhã, no canto da quitanda João Pachola (Marques, 1905, pp. 189-190).

O sentimento de profunda intimidade na relação entre as comadres, transmitida ao leitor através da interpelação desabusada de Eusébia à sua amiga nas três primeiras linhas do texto, é o suporte ficcional que justifica a estrutura dialógica do conto. Toda a narrativa se passa na forma de um diálogo entre a personagem central e a mulata Libania, e, depois, com a velha beata tia Puluquéria. O recurso é eficaz para os propósitos regionalistas do autor, na medida em que torna obrigatória a referência constante ao universo cultural e social das personagens sob pena de comprometer o efeito de realidade intentado bem como a coerência formal da narrativa.

Não é à toa que o relato de uma amizade se transforma rápida e instantaneamente na história da abolição do trabalho escravo no Brasil. Serem escravizadas pela mesma 
família no interior do Maranhão, vendidas para a capital sob o chicote do mesmo senhor, e libertadas pelo afã de status social deste proprietário, constituem o elo fundamental entre Eusébia e Libania. O sobrenome "das Carneiros" nomeia a violência social que as une desde sua provável escravização ilegal, pois nenhuma delas "havia concorrido com uma só unidade para aumentar os algarismos da estatística da população", até a avareza do último dono que só as libertou "na antevisão do aceleramento com que se aproximava a extinção do elemento servil", convertendo a futura impossibilidade de lucro econômico em reconhecimento social dado o "gesto filantrópico".

Nesse sentido as diferenças de comportamento, personalidade e modo vida com que Astolfo Marques rapidamente pinçou suas personagens perfazem a formalização estética de significados e estratégias de construção social da liberdade na ordem pós-escravocrata. Assim temos que, na relação entre as duas comadres, aquilo que o cativeiro havia unido a abolição terminou por separar. Para Eusébia, a alforria significava independência do espírito e autonomia pessoal. Apesar de bela "não morria lá de amores pelos homens": preferia morar em casa de patrões que viver subordinada por um amásio ou mesmo um marido. Além do mais gostava de viver no núcleo mais urbano e comercial da cidade, em oposição aos bairros rurais e afastados do centro de São Luís, "para estar a par das novidades", ser senhora de sua própria realidade.

Libania era diferente. Vivia a liberdade nas fronteiras do amor. Astolfo Marques lança mão dos estereótipos de apetite sexual desenfreado e inconstância emotiva acerca das mulatas que já existiam há longa data na literatura brasileira. A personagem é descrita como mulata com o fim exclusivo de dar coerência à volubilidade de suas relações amorosas passadas, descritas pelo narrador como "vidinha". O fim da escravidão significou para Libania entregar-se 
a plena liberdade de escolha sexual na qual "era notável sua predileção pelos Manuéis”, referência humorística aos brancos portugueses. Mas não era só isso. A mulata havia ganhado "a sorte grande" ao lado de Manuel Casimiro. Fato que a obrigou renunciar à estimulante vida citadina, mas proveu sua emancipação com a certeza da segurança financeira que um homem apaixonado pode oferecer àquela que lhe atende os caprichos. Vejamos sua resposta à provocação de Eusébia:

- Qual, minha cheira, não me culpe. Você sabe bem que, por mim, eu não estava naquela solidão!

- Vá dizendo pros outros, morda aqui!

- E motejante apresentava o indicador à Libania. Não compreendia como pudesse haver que nos tempos presentes, ainda se escravizasse voluntariamente. Deixasse penar pra lá o Manuel Casimiro com seus achaques de hemorroidas e viesse pra 176 cidade, que Manés lhe não faltariam, aconselhava. - Isso não, minha comadre, isso é que não faço, nem nunca farei. Quem come a carne é que rói os ossos. Aturo-o, que remédio! Tratada a vela de libra, como sou, ninguém se atreverá a chamar-me ingrata, pois não darei para isso. Vou indo aguentando meu boi inté quando Deus quiser... - O que é de gosto regala a vida. Que eu vou fazer pra sua sorte? E, batendo nas costas da amiga, a Eusébia ria-se maliciosamente.

- Quando buzinar que você for ao Açougue compre-me dois quilos de carne da maçã do peito, que eu quero levar pro sítio. Lá pro meio-dia aparecerei...

- Eh! eh! minha comadre, "você ainda está André na história”. Então, você não sabe que estão botando carne fora por causa dessa doença que está andando aí? Você com aquele homem está ficando "panema”? (Marques, 1905, pp. 191-192; grifos nossos). 
O contraste entre as comadres não poderia ser mais flagrante. Para Eusébia a escolha da amiga em viver com seu amásio é uma opção de vida anacrônica. Equivale a se rebaixar voluntariamente ao status de escravo na medida em que se ancora numa relação de dependência e submissão a outrem. Ao invés das benesses do nascente trabalho livre assalariado, Libania recorre aos favores do velho patriarcalismo. Astolfo Marques cria nesta personagem a sua própria Bertoleza, escrava que, no romance $O$ cortiço, de Aluízio Azevedo, vive como serva sexual, trabalhadora explorada e negra iludida com uma falsa carta de alforria, metáfora de sua falsa liberdade, forjada pelo consorte português João Romão. Bertoleza suicida-se no fim da trama quando o amásio paga meganhas da polícia para reduzi-la de novo à escravidão. Libania, ao contrário, por ser "tratada à vela de libra”, responde ao seu patriarca com a velha moral da "ideologia da alforria": a gratidão ${ }^{19}$. Em ambos os casos, no trágico e no irônico, estão a mesma impossibilidade de verdadeira emancipação. Moral das histórias: "quem come a carne é quem rói os ossos”.

Aliás, por citar um provérbio, merece destaque o esforço do autor em transmitir à linguagem escrita a tônica dos falares da população negra pobre de São Luís no início do século XX. O uso de termos e expressões como "minha cheira", "manés", "panema", além de provérbios como "vou aguentando meu boi inté quando deus quiser" e "o que de gosto regala a vida" dentre outros, pretendem convencer o leitor que "a opinião de Eusébia" e de outros personagens relevantes será emitida em seus próprios termos, com

\footnotetext{
19 "A ideia aqui era convencer os escravos de que o caminho para a alforria passava necessariamente pela obediência e fidelidade em relação aos senhores. Mais ainda, e como veremos detalhadamente adiante, a concentração do poder de alforriar exclusivamente nas mãos dos senhores fazia parte de uma ampla estratégia de produção dos dependentes, de transformações de escravos em negros libertos ainda fiéis e submissos a seus antigos proprietários" (Chalhoub, 1990, p. 100).
} 
o sotaque distintivo do universo cultural negro e mestiço do povo maranhense. Esse movimento contém aquele processo inesperado das relações entre a literatura e os grupos subalternos na qual o código erudito é atravessado pela irredutibilidade da presença social da diferença na realidade esteticamente reconstruída (Hardman, 1983). Eis um fato radical na ficção de Astolfo Marques que faz a escrita começar seu trabalho codificador e decodificador desde o chamado "lugar de negro".

A escolha de personagens femininas aprofunda ainda mais esse aspecto. A ocupação do espaço urbano de São Luís por mulheres negras e pobres, vivendo em cortiços e baixos de sobrado, com bancas de frutas e quitutes, lavando roupa nas fontes públicas, entoando altos pregões, é motivo de tensão e escândalo público desde os tempos imperiais. A historiadora Glória Correia ao pesquisar a mão de obra feminina na indústria têxtil maranhense notou uma 178 perseguição especial com relação às peixeiras, queixas "quase sempre apresentadas em defesa da moral e no mais ácidos dos tons, tais reclamações repetiam a mesma cantilena sobre o comportamento irreverente e a língua solta dessas trabalhadoras" (Correia, 2006, p. 35). Lembremos que, quando Eusébia encontra sua comadre, "vinha da praia do desterro com uma cambada de peixes no balde". Mais uma referência que permite inferir que o autor quis dar à personagem central do conto a irreverência escandalizadora e as maneiras desbocadas das trabalhadoras de rua. Note-se a linguagem chula e imoral de Eusébia, ao sugerir que Libania deixe o companheiro com "seus achaques de hemorroidas e viesse pra cidade, que Manés lhe não faltariam”.

Uma estratégia literária que confere mais efeito de realidade à personagem central encontra-se presente no momento em que, de repente, o relato da peste bubônica começa a emergir para o primeiro plano da narrativa, cifrado na relação entre as comadres. Bem-informada sobre os 
assuntos da cidade, mais uma vez Eusébia repreende o modo de vida da amiga quando esta lhe pede para comprar carne em plena epidemia. Mas quando Libania perguntou como tudo tinha começado ela se embaraçou para explicar:

Desde a história da carne de vaca lá pras bandas do largo dos Amores que a coisa aparecera e disseram ser peste borbonica. Foi então que os moradores daquele bairro fizeram as suas malas e "tiraram o copo", deixando o lugar deserto completamente. Ninguém mais quisera saber do peixe trazido à Praia do Genipapeiro pelas canoas do Carneiro e do Florentino. Os caboclos das bandas do Calhau e do Turu passavam de largo, e afrontando o vento esperto, com risco de ter seus cascos alagados, iam ter à praia de Santo Antonio. Era um atropelo de nossa morte. E depois o incômodo foi da gente sujeitar-se a tal desinfeição. Ela mesmo não consentiria tal coisa na sua casa, se tivesse. Defumador por defumador bastava o que ela fazia todas as sextas-feiras, no seu quarto: um fogareiro pequeno de barro, um pouco de incenso, pastilhas e benjoin, uma lasquinha de pau de Angola, pra afugentar as bruxas, isto quanto a casa; e quanto a seu corpo: numa banheira-d'água do sereno, uma infusão de murta, orisa, jardineira, folha-grossa, jasmim, tipi e uns dentinhos-d'alho, e estava feito o negócio, desinfeitados casa e corpo. Estavam também com uma história de vacina, chiringamento, nas costas ou na barriga, o que não ia com ela, que se tratara de bexigas, em casa da Canuta e não vira tanto arreganho e tamanho alarido (Marques, 1905, pp. 192-193).

O trecho acima poderia ser lido teleologicamente com uma genealogia moral da Revolta da Vacina. Astolfo Marques converte o discurso do "problema da higiene" no confronto cultural entre a experiência popular tradicional e os valores de "racionalidade", "progresso" e "ciência", impressos na política sanitária republicana. O drama da epidemia 
é visto das canoas do Carneiro e do Florentino, pescadores pobres e caboclos, que não conseguem mais vender seu peixe na cidade. A partir do manuseio desajeitado do vocabulário científico, marcado em itálicos como "peste borbonica" para peste bubônica, "desinfeição" como desinfecção e "chiringamento" na qualidade de vacinação. Sotaques que enfatizam a autonomia, irreverência e singularidade desse mundo simbólico.

Esse aspecto é central para interpretar "A opinião de Eusébia”. Algumas linhas atrás destacamos a inflexão estética que justifica essa opção, mas resta abordar seu teor ideológico. Todo esforço do autor nesse "conto de intervenção" é deslocar ficcionalmente a posição passiva e reativa do povo enquanto objeto da política sanitarista para descrevê-lo à luz de seus próprios medos, crenças e razões. Para Eusébia, de nada adianta realizar a desinfecção da casa se não temos à mão uma lasquinha de pau 180 de angola para afugentar as bruxas que infestam os lares. Não há também qualquer razão para se submeter à vacinação e ao alarido dos doutores se quanto à doença de bexigas (varíola) as seringas podem ser dispensadas. $\mathrm{O}$ discurso da ex-escrava transpõe para um idioma negro os sentidos e significados de ciência, racionalidade e modernidade no Brasil.

- Você ainda não viu o melhor... Pois até os pobres dos ratos, nascidos e criados ao Deus dará nos canos do Ribeirão, não foram mortos de surpresa? [...] Disque deram combate neles, tal como se faz no Fardango lá das Barraquinhas. A Joana Pau-Bonito, na rua da Fundição, teve de mudar-se às pressas para tocarem fogo na palhoça onde ela morava. E no meio de tudo isso quem mais sofre, já se vê, é a pobreza... Os ricos se arremedeiam, não se importam que a farinha e o jabá subam de preço... Era só que nos faltava, essa doença agora! 
- $\mathrm{E}$ você não tem medo, minha comadre?

- Eu! Oras quaes! Então você não me conhece? Até me rio dessa patacoada. Os brancos lá em casa vivem a toda hora às voltas com crioulinha, o defumador da moda, quando nos tempos da bexiga doutor Maia mandava que se queimasse breu e mais breu e a coisa foi-se. Hoje é um angu, uma misturada, que até parece que a gente pega a cuja mais depressa... É um reboliço, senhora! Seu Gamboa, seu Garvão, seu Nazareth, na tal estufa, Rezendo, de tia Ignez de prantão na Ingenhe, lá na Escola Onze de Agosto, que já nem se fecha, e muitos homens de lá nem pregam mais os olhos.

Pela cidade, a toda hora, é um barulho de carro de nossa morte, e diz-se por bocas pequenas que o governo, só de carros, para a seu Batazá cem mil réis por dia! O doutor que veio do Rio disse que é borbonica, e também pegou, mas tem também alguns doutores daqui desses mais velhos e mais aquilatados, e ainda um outro lá da terra de onde vem portugueses pra cá, que disseram lá pros meus brancos que é febre passageira... E vive a gente nessa dipindura, metida nessa bandalheira... Se isto continuar pego nos meus cacaréus, faço minha trouxa, e vou empoleirar-me na minha terra, ou então vou pra Vargem Grande, só para me ver livre desse baculejo dessa patuscada macha!

- Pois eu não sabia, minha comadre, dessa doença...

- Não é coisa de maior, senhora, é andaço e mais nada. Eles são que andam com tamanho espalhafato. S. Sebastião há de ser por nós com as preces que estão se fazendo (Marques, 1905, pp. 194-195).

O relato da peste ganha completamente o primeiro plano da narrativa. Astolfo Marques denuncia na voz de suas ex-escravas toda a brutalidade da política de higiene como a principal responsável pelo non sense popular quanto aos verdadeiros perigos trazidos pela epidemia. A hierarquização 
social das medidas sanitaristas é tão bizarra - lembremos os caprichos nos cuidados do "doentinho de classe" mencionado no relatório médico - que, para as personagens, muito daquilo não passa de "espalhafato", "moda", "andaço", "patuscada" e "confusão" das classes abastadas. Confrontadas pelo caráter desigual de uma modernidade que lança em chamas pobres casebre de palha, Eusébia e Libania agarram-se ao senso comum forjado nos embates da vida em cativeiro.

Observe-se o deboche com que Eusébia descreve "seus brancos" "a toda hora às voltas com crioulinha, o defumador da moda", em meio a "um angu", "uma misturada que até parece que a gente pega a cuja mais depressa". Tudo pela teima de não seguir as receitas que deram certo no passado como a queima de carvão para a desinfecção, dar ouvidos aos médicos que vem de fora, desconsiderando "os doutores daqui desses mais velhos e mais aquilatados" 182 que dizem ser o mal passageiro, sem contar o desperdício de dinheiro público com os carros contratados para a remoção de corpos. Enfim: do ponto de vista da ex-escrava, tem-se a criação de inúmeros "problemas artificiais" em nome de uma nova racionalidade e eficiência que redundam para a população pobre em velhos problemas como a fome e o desabrigo.

Esse é o sentido da valorização da cultura popular na obra ficcional de Astolfo Marques. Para autor, é na tão propalada "ignorância" e "indolência" do "populacho", através da tagarelice desenfreada de pretas e mulatas pelas esquinas destruindo o sossego público e os bons costumes, no senso comum nascido da escravidão, que o horizonte ativo da luta por direitos e a conquista da cidadania torna-se possível. A indignação das personagens com a subida do preço da farinha e do jabá é indissociável de suas crenças de que também os ratos merecem a misericórdia divina. Um ethos precário que inventou um cotidiano subvertido, no 
instante em que desigualdade da República oligárquica ameaçou a expressão concreta da liberdade conquistada na abolição. O lugar mais próximo do calor de uma palhoça em chamas e nossa moderna identidade brasileira.

\section{Matheus Gato de Jesus}

é mestre em Sociologia pela USP.

\section{Referências bibliográficas}

ALBUQUERQUE, W. R. 2009. O jogo da dissimulação. São Paulo: Companhia das Letras.

ALONSO, A. 2010. "A teatralização da política: a propaganda abolicionista”. Texto apresentado no Seminário Sociologia, História e Política do PPGS-USP. São Paulo (mimeo.).

ALMEIDA, A. W. B. 2008. Ideologia da decadência. Amazonas: Casa 8/Fundação Universidade do Amazonas.

ALMEIDA, M. C. P. 2004. "Saúde pública e pobreza: São Luís na Primeira República”. In: COSTA, Wagner Cabral. História do Maranhão: novos estudos. São Luís: Edufma.

BORRALHO, J. H. P. 2000. Terra e céu de nostalgia: tradição e identidade em São Luís do Maranhão. São Paulo: Ed. Unesp.

CARVALHO, J. M. 1987. Os bestializados. São Paulo: Companhia das Letras. CARVALHO, M. A. 2008. "Intelectuales negros en el Brasil del siglo XIX" In: ALTAMIRANO, C. (org.). Historia de los intelectuales en América Latina. Buenos Aires: Katz Editores, 2008.

CAMPOS, H. 1935. Memórias inacabadas. São Paulo: W. M. Jackson.

CHALHOUB, S. 1990. Visões da liberdade. São Paulo. Companhia da Letras. CORRÊA, R. 1993. Formação social do Maranhão: o presente de uma arqueologia. São Luis: Sioge.

CORREIA, M. G. G. 2006. Nos fios da trama: quem é essa mulher? Cotidiano e trabalho do operariado feminino em São Luís na virada do século XIX. São Luís: Edufma.

CORTÁZAR, J. 1993. Valise de Cronópio. São Paulo: Perspectiva.

COSTA, W. C. 2002. "Ruínas verdes: tradição e decadência nos imaginários sociais". Cadernos de Pesquisa UFMA, vol. 12, no 1-2, pp. 79-105.

COUTINHO, M. 2007. Memória da advocacia no Maranhão. São Luís: Clara.

DARNTON, R. 1986. O grande massacre de gatos e outros episódios da história cultural francesa. Rio de Janeiro: Graal.

DOMINGOS BARBOSA, D. [1911] 2008. Silhuetas. São Luís: AML/Uema. 
FERREIRA, L. A. 2004. "Os clubes republicanos e a implantação da República no Maranhão (1888-1889)”. In: COSTA, W. C. (org.). História do Maranhão: novos estudos. São Luís: Edufma.

GODINHO, V. 1904. A peste no Maranhão. São Luís: Tipogravura Teixeira. GODÓIS, A. B. B. [1904] 2008. História do Maranhão. São Luís: AML/Eduema. GOMES, A. C.; ABREU, M. 2009. "Apresentação”. Tempo, vol. 13, no 26 , pp. 1-14.

GOMES, F. 1991. "No meio das águas turvas (Racismo e cidadania no alvorecer da República: a Guarda Negra na Corte - 1888-1889)”. Estudos Afro-Asiáticos, no 21, pp. 75-96.

GOTLIB, N. B. 2002. Teoria do conto. São Paulo: Ática.

GUIMARÃES, A. S. 2010. “A República de 1889: utopia de branco, medo de preto (A liberdade é negra, a igualdade é branca e a fraternidade é mestiça”. Texto apresentado no Congresso República e Utopia do Instituto de Ciências Sociais da Universidade de Lisboa. Lisboa (mimeo.).

HARDMAN, F. F. 1983. "Palavra de ouro, cidade de palha". In: SCHWARZ, R. (org.). Os pobres na literatura brasileira. São Paulo: Brasiliense.

LEAL, P. N. 1897. "Prefácio". In: O Estado do Maranhão em 1896. Maranhão: Oficial.

184 LOBO, A. L. [1909] 2008. Os
nhense de Letras/Ed. Uema.

MARANHÃO. 1976. Astolfo Marques: publicação comemorativa do centenário de seu nascimento. São Luís: Sioge, 1976.

MARQUES, A. 1905. A vida maranhense. São Luís: Tip. Frias. 1913. A nova aurora. São Luís: Tip. Teixeira.

MARTINS, M. J. B. 2006. Operários da saudade. São Luís: Edufma.

MEIRELES, M. 1958. Antologia da Academia Maranhense de Letras. São Luís: Imprensa Oficial.

MICELI, S. 2001. Intelectuais à brasileira. São Paulo: Companhia das Letras.

NASCIMENTO MORAES. 1910. Puxos e repuxos. São Luís: Tip. do Jornal dos Artistas.

NEEDELL, J. D. 2010. "Brazilian abolitionism, its historiography, and the uses of political history". Journal of. Latin American Studies, vol. 42, pp. 231-261.

OLIVEIRA, A. 1976. "O centenário de um contista maranhense”. O Estado do Maranhão, 10 mar.

PAXECO, F. 1922. Geografia do Maranhão. São Luís: Tipogravura Teixeira.

PIGLIA, R. 2004. Formas breves. São Paulo: Companhia das Letras.

PONTIEIRI, R. 2008. "Formas históricas do conto: Poe e Tchékhov". In:

BOSI, V. (org.). Ficções: leitores e leituras. Cotia: Ateliê. 
PRADO, A. A. 2004. Trincheira, palco e letras. São Paulo: Cosac Naify.

RAMOS, G. 1995. Introdução crítica à sociologia brasileira. Rio de Janeiro: Ed. UFRJ.

SANTOS, J. R. 1995. “O negro como lugar”. In: RAMOS, G. Introdução crítica à sociologia brasileira. Rio de Janeiro: Ed. UFRJ.

SCHWARZ, R. 2000. Ao vencedor as batatas. São Paulo: Ed. 34.

SEVCENKO, N. 2010. A Revolta da Vacina. São Paulo: Cosac Naify.

SOUZÂNDRADE, J. 2003. Poesia e prosa reunidas de Souzândrade. WILLIANS,

F. G.; MORAES, J. (orgs.). São Luís: Edições AML.

VENTURA, R. 1990. “'A nossa Vendeia’: Canudos, o mito da Revolução

Francesa e a constituição de identidade nacional-cultural no Brasil”. In:

Revista do Instituto de Estudos Brasileiros, vol. 31, pp. 129-145.

VIEIRA FILHO, D. 1951. "Os escritores maranhenses". Revista do Maranhão, vol. I, fasc. VI, p. 5-6.

VIVEIROS, J. 1954. História do comércio do Maranhão. São Luís: ACM.

WILLIANS, F. G. 1976. Sousândrade: vida e obra. São Luís: Sioge.

\section{Outros materiais}

\section{Periódicos}

A Pacotilha (1900-1918)

O Diário do Maranhão (1900-1918)

O Globo (1889)

Revista do Norte (1900-1905)

Os Novos (1900-1904) 


\section{TEMPO E MELANCOLIA: REPÚBLICA, MODERNIDADE E CIDADANIA NEGRA NOS CONTOS DE ASTOLFO MARQUES (1876-1918)}

\section{MATHEUS GATO DE JESUS}

Resumo: A história da Proclamação da República na periferia setentrional do Império brasileiro (1822-1889), assim como as especificidades de suas consequências culturais na região, ainda carece de análises mais detalhadas. No Maranhão de fin de siècle, a crise econômica do sistema agroexportador, somada à crise política do trabalho escravo, legou às primeiras décadas do regime republicano uma intensa luta social em torno da definição dos limites da cidadania, na qual a subalternização racial da população negra é um ponto decisivo. O presente trabalho é uma aproximação desses impasses através da obra ficcional do escritor negro maranhense Raul Astolfo Marques (1876-1918). Filho de uma cafusa livre, o autor é fruto da geração de descendentes escravos que se debateu com a fragilidade da liberdade conquistada na Abolição e do formalismo da igualdade outorgada em 15 de Novembro de 1889. Uma parte significativa da sua literatura poderia ser entendida como uma tentativa sistemática de interpretar essas esperanças e frustrações. O tema da República comparece ao longo de toda a sua trajetória intelectual em textos como "Abnegação" (1901), "A última sessão" (1903), "O discurso do Fabrício" (1903), “A opinião da Euzébia" (1904), "De coroa e barrete" (1908) e "Reis republicanos" (1916). Resta dizer que A nova aurora (1913), seu único romance, é inteiramente dedicado à descrição dos primeiros meses de implantação do regime republicano. Na primeira parte do ensaio indagamos quais "versões da história" e episódios significativos orientam a reconstrução 
ficcional das consequências do 15 de Novembro na periferia do Brasil, focalizando o conto "O discurso do Fabrício" e a crônica "A última sessão". No segundo momento, abordamos o tratamento literário dado pelo autor ao problema da política pública republicana no governo Rodrigues Alves (1902-1906), período auge da ideologia sanitarista no país e com tremendo impacto no Maranhão, devido à eclosão da peste bubônica no início de 1904. Nesse sentido, articulando texto, pré-texto e contexto, visa-se desvendar os caminhos de uma escolha literária orientada por um ambiente cultural cada vez mais insulado e periférico no jogo político oligárquico nacional, de hegemonia paulista e mineira, mas também mediado por relações de dependência socioeconômica e subordinação racial.

Palavras-chave: República; Modernidade; Cidadania; Maranhão; Intelectuais negros.

\section{TIME AND MELANCHOLY: REPUBLIC, MODERNITY AND BLACK CITIZENSHIP IN THE SHORT STORY OF ASTOLFO MARQUES (1876-1918)}

Abstract: The history of the Republic Proclamation in Northern periphery of the Brazilian Empire (1822-1889), as well as the specificities of its regional cultural consequences still lack more detailed analysis. In Maranhão fin de siècle, the economic crisis of agro-export system added to the slave labor political crisis bequeathed to the republican regime early decades an intense social struggle around the definition of the citizenship boundaries, in which the racial subordination of black people is a crucial point. This paper looks closer to these deadlocks through the fictional work of the black writer Raul Astolfo Marques (1876-1918). Son of a free cafusa, the author is an outgrowth of a generation of slave descendants who have floundered in the fragility of freedom conquered in the formalism of Slave Abolition and equality, granted on November 15, 1889. A significant part of his literature can be understood as a systematic attempt to interpret these hopes and frustrations. 
The republic subject appears throughout his intellectual career, in writings e.g. "Abnegação" (1901), "A última sessão" (1903), "O discurso do Fabrício" (1903), “A opinião da Euzébia” (1904), "De coroa e barrete" (1908) e "Reis republicanos" (1916). It remains to be said that his only novel A nova aurora (1913) is entirely devoted to the description of the first month of republican regime implementation. In the first part of the present paper, I ask which "versions of history" and significant episodes guide his fictional reconstruction of the November 15th 1889 consequences, focusing the short story "O discurso do Fabricio" and the chronicle "A última sessão". In the second part, I discuss the literary treatment given by the author to the problem of public policy in Rodrigues Alves (1902-1906) republican government, the heyday of sanitation ideology in the country, with tremendous impact in Maranhão due to the outbreak of bubonic plague in early 1904 s. In this respect, combining text, pre-text and context, it is intended to unveil the pathways of a literary choice guided by an 320 increasingly insulated and peripheral cultural environment in the oligarchic political game with hegemony of São Paulo and Minas Gerais, but also mediated by dependent socio-economic relations and racial subordination.

Keywords: Republic; Modernity; Citizenship; Maranhão; Black intellectuals.

Recebido: 29/07/2011 Aprovado: 17/10/2011 